\title{
DOGAĐAJ I ETNIČKA SITUACIJA: PROMJENE IDENTITETA NACIONALNIH MANJINSKIH ZAJEDNICA U REPUBLICI HRVATSKOJ
}

MARINA PERIĆ KASELJ

FILIP ŠKILJAN

ALEKSANDAR VUKIĆ

Institut za migracije i narodnosti

10000 Zagreb, Trg Stjepana Radića 3
DOI: $10.17234 /$ SEC.27.1

Izvorni znanstveni rad

Primljeno: 1. 3. 2015.

Prihvaćeno: 24. 6. 2015.

U radu se izlažu rezultati istraživanja (re)konstrukcije etničkih/nacionalnih identiteta pojedinih manjinskih zajednica u Republici Hrvatskoj uvjetovanih promjenama društvenopovijesnog konteksta (u razdoblju kad se Hrvatska nalazila u sastavu SFRJ, potom u razdoblju demokratskih promjena, Domovinskog rata, i samostalne RH). Koristi se kvalitativni pristup koji s jedne strane uključuje propitivanje službenog kategoriziranja i klasificiranja nacionalnih manjinskih zajednica unutar Ustava SFRJ i Ustava RH, teorijsko-pojmovnih objašnjenja $i$ njihovoj implementaciji u definiranju identiteta, te empirijski dio koji obuhvaća dubinske intervjue maksimalne varijacije s pripadnicima različitih nacionalnih manjinskih zajednica koji žive na širem području RH. Naglašava se kako određene institucionalizirane klasifikacijske sheme ili povijesni trenutak mogu nametnuti ili dovesti do promjenjivosti strategija, položaja $i$ uloge određenih manjinskih zajednica. Osim službenih definicija i institucionaliziranih klasifikacijskih shema kojima se neposredno pripisuju određena identitetska svojstva pojedinoj grupi, društveni identiteti mogu biti i rezultat slobodnog izbora, prinude, strategijske igre samih pojedinaca/članova određene grupe ili resurs podložan mobilizaciji u ostvarivanju političkih ili ekonomskih ciljeva. Kroz ova dva pristupa analizi identiteta nacionalnih manjinskih zajednica u RH pojašnjavamo ne samo procesualni i dinamični karakter identiteta nego i njegovu promjenjivu i situacijsku prirodu.

Ključne riječi: etnička situacija, događaj, identitet, etničke grupe, nacionalne manjine, nacionalne manjine u Hrvatskoj

\section{UVOD}

Interakcije i suživot većinskog i manjinskog naroda, stalna migracijska kretanja, promjena granica i društveno-političkih sistema i povremeni ratni sukobi značajka su hrvatskog prostora i povijesti. Držimo kako hrvatski prostor i povijest u gotovo "laboratorijskim" uvjetima pružaju istraživačima mogućnost da odgovore na neka prijeporna teorijska 
pitanja o etničkom identitetu. Naš se rad u epistemološkom smislu temelji na Luhmannovu (2001b) načelu po kojem se sistem konstruira i održava operacijom promatranja kroz procese razlikovanja i označavanja. Iz takvog pristupa nastaje temeljni istraživački program (metoda) sistemskog pristupa. U takvom teorijskom okviru transformacije identiteta etničkih skupina nisu posljedica kulturnih razlika među njima nego je posrijedi spoznajni proces u kojem promatrači razlikovanjem proizvode različitost (Bateson 1979:99).

Drugi istraživački program jest promatranje promatrača i njihovih razlikovnih kodova, opisa, kategorizacija i klasifikacijskih sustava. Tada se mogu razumjeti mehanizmi kojima promatrački aparati koji imaju moć definiraju etničke situacije, te procese kojima se ta "mikrofizika moći” manifestira u etničkim situacijama. Iz toga slijedi Luhmannova metodološka uputa - promatraj promatrače i njihove opise situacije. "Promatrači često mogu bolje predvidjeti djelovanje na temelju poznavanja situacije nego na temelju poznavanja ličnosti, i u skladu s tim, njihovo opažanje često, ako ne pretežno, čak ne odgovara mentalnom stanju aktera." (Luhmann 2001a:240). U tom je smislu i naš pristup u ovom radu temeljen na promatranju djelovanja države i njezinih institucija, s jedne strane, te analizi diskursa manjinskih zajednica u Hrvatskoj koji su rezultat promatranja i razumijevanja vlastite pozicije u etničkoj situaciji, s druge strane. U tom smislu glavna istraživačka metoda sociologa, povjesničara ili antropologa trebala bi biti interpretativna. Jer kako je pokazao još Geertz (1973), društvene se znanosti ne bi trebale baviti "objektivnim činjenicama" nego interpretacijama tih činjenica, i interpretacijom tih interpretacija. To je uostalom i jedino što preostaje promatračima drugog, trećeg i n-tog stupnja. Iz tih epistemološko-teorijskih pozicija razvija se i središnje istraživačko pitanje: kako se unutar različitih društvenopolitičkih sistema organizira temeljni, za društvene sustave konstitutivni odnos većine i manjine, odnosno odnos “inkluzije i ekskluzije” pojedinaca i društvenih, a napose etničkih grupa? Koji su to čimbenici koji dovode do mobilizacije, destabilizacije ili revitalizacije mnogostrukih vidova etničkog identiteta, i na koji se način (re)konstruira identitet u različitim etničkim situacijama? 


\section{METODOLOŠKO-POJMOVNA OBJAŠNJENJA}

Kako bi prikazali načine (re)konstruiranja identiteta pojedinih manjinskih zajednica na prostoru RH, i pritom testirali model etničke situacije, u istraživanju smo primijenili kvalitativni metodološki pristup. Polazeći od naših teorijskih postavki, istraživanje smo započeli interpretativnom analizom klasifikacijskih shema i definiranja nacionalnih manjina na oficijelnoj službenoj razini Ustava SFRJ i Republike Hrvatske. Empirijski dio istraživanja obuhvatio je 50 dubinskih polustrukturiranih intervjua ${ }^{1}$ maksimalne varijacije s pripadnicima nekoliko različitih nacionalnih manjinskih zajednica koji žive u različitim mjestima/regijama unutar RH. Prilikom definiranja nacionalnog identiteta naglasak smo stavili na socijalne konstrukte kao što su kolektivna sjećanja, kolektivna krivnja, stigmatizacija, koji dovode do različitih oblika potisnutog, prikrivenog, zamjenskog ili izmišljenog identiteta. Pokazujemo kako određene institucionalne shematske klasifikacije ili povijesni Događaj mogu nametnuti ili dovesti do promjene strategija samoopisivanja određene etničke (manjinske) grupe koji je, držimo, uvijek usko povezan s promjenom etničke situacije. Osim prirode nacionalnog/etničkog identiteta, osvrćemo se i na pojedine subjektivno-objektivne kriterije koji mogu biti relevantni u objašnjenju i definiranju nacionalnog/etničkog identiteta. Na taj način pojašnjavamo ne samo procesualni i dinamični karakter identiteta nego i njegovu promjenjivu i situacijsku prirodu. Stoga za oblikovanju identiteta etničkih (nacionalnih) manjinskih zajednica smatramo važnim povijesno naslijeđe. Svaka nacionalna zajednica ima jedinstveno iskustvo i povijest (Buzan 1991), i kao takva razvit će vlastiti i jedinstveni kolektivni identitet. Isto tako, bitno nam je odrediti u kojem se vremenu kolektivni identitet stvara odnosno koliko je on uvjetovan određenom etničkom situacijom ili određenim društvenim, političkim i ekonomskim kontekstom.

\footnotetext{
${ }^{1}$ Intervjui su vođeni u razdoblju od 2010. do 2014. godine prema unaprijed dogovorenim uvjetima kroz kontakte i dogovor s institucionalnim predstavnicima nacionalnomanjinskih zajednica koji su sudjelovali u organizaciji dolaska ispitanika te osiguranju prostora za vođenje intervjua. $U$ radu ispitanike navodimo inicijalima imena i prezimena, godinom rođenja i mjestom življenja.
} 
Kad govorimo o identitetu nacionalnih manjinskih zajednica, koristit ćemo pojam etnička/nacionalna zajednica i etnički i nacionalni identitet kao sinonime jer je riječ o manjinskim nacionalnim zajednicama koji ne žive $u$ svojim matičnim državama nego na području Republike Hrvatske.

\section{ETNIČKA SITUACIJA, DOGAĐAJ I IDENTITET ETNIČKIH GRUPA}

Etnička situacija jest teorijsko-promatrački model koji omogućuje da se konkretno promatrana etnička situacija smjesti u odgovarajući sinkronijski (prostorni) i dijakronijski (povijesni) kontekst. Etnička je situacija analitički promatrački aparat koji se nalazi u oku promatrača. Promatrači su po Luhmannovoj konstruktivističkoj epistemologiji funkcionalno izdiferencirani sustavi društva - znanost, umjetnost, politika, pravo, te organizacije, napose država. Naš model etničke situacije obuhvaća prostornovremenski kontekst obuhvaćen promatranjem, sudionike-pojedince (aktere) i državu - nadzorno-klasifikacijski aparat s monopolom političke moći. Strukture i procesi u etničkoj situaciji (u ovom slučaju hrvatskoj) održavaju se kroz neprekidnu komunikaciju i interakciju. Događaj se nadovezuje na događaj u interakciji, a iskaz na iskaz u komunikaciji. S vremenom se interakcije i komunikacije rutiniziraju, institucionaliziraju i nastaju relativno čvrste strukture odnosa koje odterećuju sudionike od razmišljanja što učiniti u svakoj konkretnoj situaciji (Berger i Luckmann 1992:42-45). U svijetu rutiniziranog događanja i komuniciranja poneki put se "pojavljuje" Događaj u smislu koji tom pojmu pridaje A. Badiou (2005:173-178). Događaj se prepoznaje po tome što on, za razliku od uobičajenih događaja, automatski utječe na promjenu etničke situacije. Nakon njega ni prošlost ni budućnost sudionika u etničkoj situaciji ne mogu ostati jednake. Vjerodostojan opis etničke situacije pretpostavlja promatranje funkcije države kao organizacije koja koncentrira moć na određenom teritoriju i njezine uloge u oblikovanju etničke situacije. Svoju moć ona ostvaruje kroz mehanizme promatranja, nadgledanja, nadzora, imenovanja i kategoriziranja društvenih grupa i pojedinaca koji čine stanovništvo države. ${ }^{2}$

\footnotetext{
${ }^{2}$ Podrobniji prikaz tih funkcija države vidjeti u radu Moć klasifikacije: klasifikacijske sheme i konstrukcija etničke strukture u Banskoj Hrvatskoj i Slavoniji (1785.-1860.) (Vukić 2008).
} 
Za hrvatsku etničku situaciju takvi su Događaji bili pobjeda antifašista (komunista) u Drugom svjetskom ratu i odluka o razdruživanju od Socijalističke Federativne Republike Jugoslavije (SFRJ) i stvaranje Hrvatske kao nacionalne države. Hrvatska je država, uostalom kao i svaka druga, počela obavljati svoje osnovne funkcije: prebrojavanje stanovništva, nadziranje, kažnjavanje, izdavanje zakona i uredbi, sve temeljeno na novoj klasifikacijskoj shemi stanovništva. Polazeći od Luhmannova (2001b) načela po kojem se sistem konstruira i održava operacijom promatranja kroz procese razlikovanja i označavanja, $u$ istraživanju smo osobitu pozornost posvetili opisima i samoopisima promatrača (države kao klasificirajućega nadzornog aparate te pripadnika etničkih grupa), te njihovu logičkom grupiranju u sustave klasifikacije ljudskih kolektiviteta, diskursa, pogleda na svijet i konstrukcije različitih identiteta. ${ }^{3}$

\section{NACIONALNE MANJINE I NJIHOV USTAVNI POLOŽAJ UNUTAR SFRJ/RH}

U Odluci o izgradnji Jugoslavije na federativnom principu, koja je službeno prihvaćena 1943. godine u Jajcu, doneseno je rješenje nacionalnog pitanja u Jugoslaviji na bazi pune ravnopravnosti svih naroda Jugoslavije. Načelno su dogovorena i prava nacionalnih manjina. Zemaljsko antifašističko vijeće narodnog oslobođenja Hrvatske 9. svibnja 1944. godine donijelo je Deklaraciju o osnovnim pravima naroda i građana Demokratske Hrvatske u kojoj je proklamirano kako će se "nacionalnim manjinama u Hrvatskoj osigurati sva prava na nacionalni život". Ustavom iz 1963. godine prvi se put uvodi termin "narodnost". Ponovljena je odredba o pravu nacionalnih manjina da slobodno upotrebljavaju svoj jezik i razvijaju vlastitu kulturu, ali se u tome cilju dodaje i pravo na osnivanje manjinskih organizacija. Ustav sadrži i temeljno pravilo o školama za pripadnike pojedinih nacionalnih manjina, a prema njemu, nastava se u tim školama

\footnotetext{
${ }^{3} \mathrm{~S}$ ponešto drugačijega teorijskog motrišta o bitnoj ulozi klasificirajućih i kategorizirajućih aparata te odnosu etničnosti i nacionalizma u konstruiranju identiteta piše T. H. Eriksen (1991; 2002).
} 
održavala na jezicima nacionalnih manjina. Prema članku 43, republičkim ustavima i zakonima bilo je prepušteno da utvrde i druga prava pojedinih nacionalnih manjina. ${ }^{4}$ Bitne promjene u položaju naroda i narodnosti uvode se Ustavom SFRJ 21. veljače 1974. i tek su po njemu i od tada narodnosti postale ravnopravni sastavni dio sustava, te su nosioci suverenosti i u samoj Federaciji. Od tada se i u republičkim Ustavima koristi termin "narodnosti", ali se uz njega (osim u Ustavima BiH i Crne Gore) javlja i termin "etnička grupa". Pod "etničkom grupom" mislilo se na Rome, Vlahe i Židove. Na osnovi takvog određenja položaja čovjeka i građanina, kao prije svega pripadnika neke nacije ili etničke skupine, u Socijalističkoj je Jugoslaviji i konstruirana metodologija popisa stanovništva. Za razliku od prijašnjih popisa stanovništva i metodologija koje su primjenjivane u klasificiranju, u socijalističkoj je Jugoslaviji prvi put dozvoljeno iznošenje osobnih stavova o etničkoj i nacionalnoj pripadnosti. Svaki se građanin mogao izjasniti o pripadnosti nekoj naciji ili etničkoj skupini, ali se mogao ne izjasniti niti odlučiti za pripadnost nekom narodu ili narodnosti (čl. 170 Ustava SFRJ 1974). Bez obzira na odluku građanina, on uživa jednakost u pravima i dužnostima, jednakost pred zakonom, jer nacionalnost, rasa, spol, jezik, vjera, obrazovanje ili društveni položaj ne mogu biti razlog za diskriminaciju (čl. 154). Protuustavnim i kažnjivim smatra se svako propagiranje ili provođenje nacionalne netrpeljivosti i raspirivanje nacionalne, rasne ili vjerske mržnje. Prema Ustavu iz 1974., Jugoslavija je bila zamišljena kao federacija republika, od kojih je svaka (s iznimkom Bosne i Hercegovine) "pripadala" jednoj naciji. U okviru Srbije postojale su autonomne pokrajine Vojvodina i Kosovo koje su istodobno bile i konstitutivni dijelovi SFRJ. Prema članku 1 Ustava, SFRJ je definirana kao državna zajednica dragovoljno ujedinjenih naroda i njihovih socijalističkih republika te autonomnih pokrajina Vojvodine i Kosova. Nacijama su smatrane one etničke skupine koje imaju vlastitu republiku/državu: Hrvati, Srbi, Slovenci, Makedonci i Crnogorci. ${ }^{5}$ Status nacionalne manjine prema Ustavu SR Hrvatske imale su etničke skupine koje imaju matičnu državu

\footnotetext{
${ }^{4}$ Ustav FNRJ iz 1963. godine, Službeni list, Beograd, 1964.

${ }^{5}$ Muslimani su imali status "konstitutivnog naroda", nacije, ali je njihov položaj umnogome drukčiji zbog činjenice da nisu imali vlastitu republiku/državu.
} 
(Česi, Mađari, Rusini, Slovaci, Talijani i Ukrajinci), a položaj etničke grupe narodi bez države (Romi). ${ }^{6}$

Nacije SFR Jugoslavije smatrale su se "konstitutivnim narodima", temeljima federacije. Pripadnici nacija imali su određene prednosti na teritoriju cijele zemlje. Tako su Srbi po Ustavu SR Hrvatske bili "konstitutivni narod" Republike, sve dok nisu Ustavom iz 1990. izjednačeni sa svim ostalim nacionalnim grupama. Jedna od bitnih odrednica ravnopravnosti nacionalnih manjina u SR Hrvatskoj bilo je njihovo izravno sudjelovanje u predstavničkim tijelima i državnoj upravi na svim razinama.

Pojam manjina uveden je tek Ustavom RH od 22. prosinca 1990. godine. U Ustavu iz 1990. godine i Ustavnom zakonu o ljudskim pravima i slobodama i o pravima etničkih i nacionalnih zajednica ili manjina (1991) navodi se šesnaest manjinskih skupina ili zajednica: sedam spomenutih (Česi, Mađari, Rusini, Slovaci, Talijani, Ukrajinci, Romi), pet manjinskih zajednica koje su se oblikovale iz nekada konstitutivnih naroda tadašnje Jugoslavije (Crnogorci, Makedonci, Muslimani, Slovenci i Srbi) te oni koji iz političkih motiva (Austrijanci i Nijemci) ili iz drugih razloga (Židovi, Albanci) nisu u bivšem sustavu bili prihvaćeni kao nacionalne posebnosti na tlu Hrvatske.

Prema Ustavnom zakonu o izmjenama i dopunama Ustava Republike Hrvatske (1997), u izvorišnim osnovama Ustava kao autohtone manjine ${ }^{7}$ u Hrvatskoj navedeni su Srbi, Česi, Slovaci, Talijani, Mađari, Židovi, Nijemci, Austrijanci, Ukrajinci, Rusini i drugi, ali ne i Slovenci i Bošnjaci. Nakon prosvjeda i određenog pritiska EU-a, Ustavnim zakonom o ljudskim pravima $i$ slobodama i o pravima etničkih nacionalnih zajednica ili manjina u Republici

\footnotetext{
${ }^{6}$ Albanci, iako priznata manjina u Jugoslaviji, u Hrvatskoj unutar socijalističke Jugoslavije nisu uživali taj status, Židovi, zbog nerazlikovanja vjerskog i nacionalnog, nisu imali ustavom zajamčena manjinska prava, Austrijanci i Nijemci zbog "kolektivne krivnje nisu imali pravo na samoorganiziranje", dok Rusi, Bugari, Grci, Turci, Vlasi, Poljaci i Rumunji zbog svoje malobrojnosti i nezainteresiranosti ostaju na razini pojavnosti u Hrvatskoj.

${ }^{7}$ Pod pojmom autohtone manjine podrazumijevaju se manjine koje su više od sto godina nastanjene na tlu neke zemlje. Pojam je veoma dvojben i čini se da je dobro što se od njega odstupilo, te je Bošnjacima priznat status manjine. O ideološkim aspektima korištenja pojma “autohtoni” vidjeti u članku Irene Šumi i Alenke Janko Spreizer (2011:101-121).
} 
Hrvatskoj iz 2000. (pročišćeni tekst) status nacionalne manjine priznat je praktično svim etničkim skupinama, pa tako i Slovencima i Bošnjacima (čl. 3). $\mathrm{U}$ istom članku pobrojene su sljedeće nacionalne manjine čiju ravnopravnost štiti Republika Hrvatska: Albanci, Austrijanci, Bošnjaci, Bugari, Crnogorci, Česi, Mađari, Makedonci, Nijemci, Poljaci, Romi, Rumunji, Rusi, Rusini, Slovaci, Slovenci, Srbi, Talijani, Turci, Ukrajinci, Vlasi i Židovi.

Ovakvim rješenjem Hrvatska je načinila pozitivan pravni presedan priznajući jednaka prava svim etničkim manjinama bez obzira na njihov broj i duljinu boravka na teritoriju države. U zakonima europskih zemalja, primjerice, Romi nigdje nisu priznati kao nacionalna manjina. No posebno je revolucionarna odluka o priznavanju statusa nacionalne manjine Albancima koji su u Hrvatsku pristigli kao radnici-migranti. Dana 13. prosinca 2003. donošenjem Ustavnog zakona o pravima nacionalnih manjina Hrvatska je ispunila jedan od ključnih preduvjeta na putu prema pridruženom članstvu Europskoj uniji i istodobno cjelovito uredila pravnopolitički prostor za nesmetan razvitak manjinskih zajednica. Postavke novoga Ustavnog zakona izviru iz međunarodnih konvencija i zakona kojih je hrvatska država potpisnica, a u čijim su temeljima ključne postavke ideje multikulturalizma i miroljubive koegzistencije.

\section{DEFINIRANJE NACIONALNOG (ETNIČKOG) IDENTITETA: IZBOR, PRISILA ILI NEŠTO TREĆE?}

Definiranje identiteta od strane pojedinaca članova određene manjinske nacionalne zajednice može biti uvjetovano različitim povijesnim, političkim ili drugim čimbenicima. Kroz različite primjere pojedinih nacionalnih manjinskih zajednica, pokazat ćemo da je etnički (nacionalni) identitet "proizvod" etničke situacije u kojima etničke grupe i pojedinci koriste primordijalne, instrumentalističke i konstruktivističke strategije kako bi definirali situaciju u odnosu prema drugim etničkim grupama.

Upravo su "primordijalne"8 sastavnice identiteta, u smislu kako je taj pojam prvi upotrijebio Shils (1957), osnova održanja primarnih

\footnotetext{
${ }^{8}$ Odlična rasprava o odnosu primordijalno/instrumentalno u konstruiranju etničkog identiteta nalazi se u knjizi Irene Šumi Kultura, etničnost, mejnost.
} 
grupa i vezivno tkivo integracije i reprodukcije globalnog društva. Po Geertzu (1963), primordijalnost je kulturna činjenica koja podrazumijeva solidarnosti koju karakterizira osjećaj bliskosti (krvna veza, religija, jezik, religijska pripadnost ...). Primordijalne sastavnice identiteta etničkih grupa "zadani" su temelj na kojem se izgrađuje identitet pojedinaca, pripadnika etničkih grupa. Konstruiranje identiteta, samoopisi koje pojedinci ili etničke grupe neprekidno proizvode, ne mogu se graditi ni iz čega i proizvoljno. Zbilja svijeta i etničke situacije socijalno je konstruirana, ona je posljedica nevidljivog rada društvenih institucija, a etničke su institucije, prema Mary Douglas, svakako primordijalne, odnosno, nulte institucije (Douglas 2001).

Etnički identitet može se koristiti i instrumentalno kao resurs podložan mobilizaciji u osvajanju političke vlasti i ekonomskih dobara. Glazer i Moynihan (1975:18) ističu da su to oblici identifikacije zasnovani na različitim realnostima kao što su religija, jezik ili nacionalno podrijetlo i kojima je zajednička "činjenica da su postali djelotvorna žarišta grupne mobilizacije za konkretne političke ciljeve”. Etničnost potiče grupnu solidarnost i prikriva zajedničke specifične interese za koje se vodi borba (Cohen 1969). Etničke grupe definiraju se kao instrumentalne grupe, umjetno stvorene i održavane zbog svoje pragmatičke korisnosti (Vincent 1974). Pokazuje se da, prema navedenim autorima, etnički identitet može biti korišten kako bi se ostvarili individualni ciljevi, dok u nekim situacijama može postati sredstvo kolektivne (etničke) mobilizacije u borbi za vlast. Interakcionalisti su razvili dvije vrste teorijskih pristupa: prvi stavlja naglasak na postupke klasificiranja i kategorizacije koji upravlja procesima interakcije, a drugi pozornost poklanja pitanjima društvenih statusa.

Prvi pristup, pedesetih godina razvili su istraživači s RhodesLivingstone Institute. Etničnost se promatra kao dinamička kategorija. Etnički identitet definira se kao spoznajni okvir koji ima važnu ulogu u društvenim odnosima i u tumačenju pojedinih situacija. Etnički simboli i nazivi predstavljaju spoznajne točke, a akteri im pribjegavaju kako bi potvrdili ispravnost svoga ponašanja. Kategorije koje tvore jednu etničku skupinu uvijek su u suprotnosti jedne prema drugima, nastajanje jedne kategorije izaziva i javljanje pridruženih kategorija.

Drugi pristup koji su razvili S. M. Lyman i W. Douglass (1972) etničnost definira kao dio određene situacije u kojoj se akteri nalaze u tijeku 
svojih interakcija. Po njima, etničnost se pojavljuje kao sredstvo konstrukcije, manipulacije i modifikacije stvarnosti. Kontakti i interakcije među akterima proizvode različite situacije koje definiraju i različite identitete. Na taj način situacijska analiza etničnosti povezuje se s izučavanjem različitih strategija pojedinca (mijenjanje etničkog identiteta kao strategija za ostvarenje vlastitih interesa) u oblikovanju i izražavanju njihova etničkog identiteta.

Konstruktivisti (Cornell, Harman 1998) smatraju kako se nacionalni identitet izgrađuje i konstruira tijekom života, i ponekad je rezultat slobodnog izbora samog pojedinaca, a nekad je kombinacija naslijeđenih i zadanih i novih formiranih identiteta.

U sljedećim primjerima vidjet ćemo na koji je način nacionalni identitet pojedinih manjinskih zajednica na prostoru RH bio rezultat osobnog izbora, prisile ili nečega trećeg.

\section{KOLEKTIVNA KRIVNJA: STIGMATIZACIJA I PRISILNO ISELJAVANJE NIJEMACA}

Kolektivna krivnja jest psihološko iskustvo koje može ali i ne mora imati stvarne konotacije proživljenog - pojedini članovi grupe ne moraju sudjelovati u nanošenju štete ili nepravde drugoj grupi. Kolektivna krivnja najčešće se pojavljuje u dvama osnovnim oblicima: prihvaćanje kolektivne krivnje i pripisivanje kolektivne krivnje. Ovdje ćemo govoriti o drugom obliku kolektivne krivnje za koju je značajno da grupa kojoj je nanesena šteta želi prihvaćanje odgovornosti i kolektivne krivnje pripadnika druge grupe. Govorimo o primjeru kategoriziranja njemačke nacionalne manjine koja je živjeli na području SRH/SFRJ kao krivca na osnovi zločina koje su učinili pripadnici njihove nacije za vrijeme Drugoga svjetskog rata. Naime, Drakonskom odlukom AVNOJ-a od 21. studenoga 1944. godine sva imovina državljana Reicha i osoba njemačke narodnosti na području Jugoslavije (izuzev onih koji su se borili u jedinicama NOV-a ili su podanici neutralnih država, a nisu se držali neprijateljski tijekom rata) prelazi u vlasništvo države (Geiger 1997:31). Prema tadašnjem shvaćanju, s "folksdojčerima u Jugoslaviji treba jednom za uvek prečistiti račune" i "državu treba očistiti od manjina". "Pored čišćenja od strane vojske u toku operacije, treba primeniti i druga sredstva, da bi se narodne manjine 
prisilile na iseljavanje. Pre svega, zbog njihovog držanja u ovom ratu, treba im oduzeti sva manjinska prava. Nemilosrdno treba staviti pred ratni sud sve one članove narodnih manjina, koji su se stavili na bilo koji način u službu okupatorima. Za njih treba stvoriti koncentracione logore, njihova imanja zapleniti, a porodice im isto poslati u logore, pa prvom prilikom prebaciti u njihove nacionalne države" (Vasa Čubrilović, tadašnji sveučilišni profesor, ekspoze o protjerivanju Nijemaca, Mađara, Rumunja i Albanaca iz Jugoslavije 3. studenoga 1944. za Prezidijum Narodne skupštine Narodne Republike Srbije, u Beus Richemberg 2010:189). Prema pričanju ispitanika, pripadnika njemačke nacionalne manjine, već se 1943. godine formiraju drugačiji stavovi o Nijemcima (folksdojčerima) u Hrvatskoj, odnosno Jugoslaviji, te se nekada uzorni i vrijedni susjedi kategoriziraju kao pripadnici "nepoželjne, zločinačke nacije”.

"Godina 1943. već je dobro nagovještavala kakav će biti konačni ishod rata. Bila je to naznaka teških dana za Nijemce bez obzira na to kakvi su bili ljudi, pa je činjenica da je netko bio pošten i dobronamjeran, protivnik nacizma kao ideologije ili je naprosto žena, dijete ili nemoćni starac bila nevažna. Dovoljno je bilo biti Nijemac da bi bio obilježen." (O. K., rođ. 1939., Beli Manastir)

U to je vrijeme došlo do prisilnog premještanja, mogli bismo reći egzodusa Nijemaca iz SFRJ/RH. Njemačke su vlasti na Zapad evakuirale velik broj obitelji njemačkog podrijetla koje su se nalazile na prostorima satelitskih država. Prema vlastitim sjećanjima, slikovitu impresiju prisilnog iseljavanja Nijemaca kao i dislociranje vlastite obitelji prikazuje nam ispitanik iz Belog Manastira:

"Švabe su otišli na kolima, kao Indijanci na filmovima, u jesen 1944. Namještaj je ostao, porculan su zakopali nadajući se da će se vratiti. Neke su stvari sakrivali tako što su prezidali podrume. Kada je u Beogradu donesena odluka da su svi Nijemci neprijatelji otjerali su nas u logor. Mati i djed su ostali u Baranji. Prababu i nas djecu odveli su u Mitvar pokraj Grabovca. Bili smo tamo oko mjesec dana. Poslije su nas prebacili u Đakovo. Tamo smo pješice išli (sad kada sam vidio u posljednjem ratu Vukovar i kolone ljudi vidio sam sebe). Stric koji je bio partizan došao je po nas u logor i vratio nas kući.” (P. M., rođ. 1933., Beli Manastir) 
Velik broj Nijemca koji su ostali u Jugoslaviji ili koji su se iz Njemačke i Austrije vratili u Jugoslaviju završili su u logorima diljem zemlje. O vlastitom iskustvu proživljenog govori ispitanik:

"Naša familija uvijek je bila na samom čelu kolone u prvim redovima. Mama je nosila mlađeg brata i ono nešto što nam je ostalo u jednom koferu, baka i djeda nešto svoje sirotinje u pinklu, strina svog malog sinčića, a ja sam hodao držeći se za maminu suknju da ne zaostanem." (O. K., rođ. 1939., Beli Manastir)

Kako je vidljivo, biti Nijemac u poslijeratnoj SFRJ/RH (bez obzira na to što možda nisi sudjelovao u ratu ili što si bio tek dijete) značilo je biti pripadnik zločinačkog naroda, i po tom su obilježju stigmatizirani. Posljedice kolektivnog pripisivanja krivnje bile su zastrašujuće, a neke od njih su promjena etničke strukture naselja, izjašnjavanje Nijemaca kao Mađara ili Jugoslavena, strah od upotrebe materinskog jezika, traumatično iskustvo, stigmatiziranje/isključivanje od strane drugih i slično.

U takvim traumatskim situacijama došlo je do procesa potiskivanja pravog identiteta i prihvaćanja poželjnog ili egzistencijalno jedino mogućeg identiteta. O tome nam govore sljedeći primjeri:

"Uvijek su me zezali. Vikali su mi Švabo Švabo! Ako niste imali neke srpske korijene onda je bio problem naći posao. Mene i brata mama je uvijek izjašnjavala kao Jugoslavene. Ti si rođen u Jugoslaviji i dokle god je te države neka tako ostane, a onoga trenutka kada je ne bude tvoje je da odlučiš što ćeš biti.” (B. M., rođ. 1956., Širine)

"Ja sam znao samo njemački. Mama nas je bremzala da ne govorimo njemački. Pod tom presijom cijelog društva ja i brat smo praktički zaboravili njemački. Naučili smo mađarski i hrvatski/ srpski. Upisao sam se u školu i mama me je deklarirala kao Mađara. Biti Mađar je bilo manje nezgodno. Bilo je tada dosta pomađarenih Nijemaca. Kao Mađar sam se vodio do sedamdesetih i do tada mi se prezime pisalo s jednim L, a tek poslije s dva L.” (O. K., rođ. 1939., Beli Manastir)

U razdoblju od 1943. godine pa do devedesetih godina prošlog stoljeća nacionalni identitet njemačke manjinske zajednice na ovim prostorima bio 
je prikriven i potisnut. Tek se demokratskim procesima i raspadom SFRJ Nijemci počinju izjašnjavati kao Nijemci, pa ova nacionalna manjina postaje opet društveno vidljiva. ${ }^{9}$

\section{KOMEMORACIJA JASENOVCA - VAŽNOST KOLEKTIVNOG SJEĆANJA U OBLIKOVANJU NACIONALNOG IDENTITETA}

Ako se priklonimo individualističkom poimanju kolektivnih sjećanja, onda ćemo naglasak staviti na pojedince kao nosioce tih sjećanja. Pojedinci u svojim umovima aktiviraju kolektivna sjećanja, a usvajanjem i pridavanjem značenja kolektivna sjećanja dobivaju "uporabnu" vrijednost (Kansteiner 2002). Važnost kolektivnih sjećanja na stradanja u Drugome svjetskom ratu pokazat ćemo na primjerima Roma i Srba, a mjesto/spomenik kao (njihovo) opredmećeno sjećanje jest logor Jasenovac gdje je prema poimeničnom popisu žrtava stradalo 83145 žrtava. ${ }^{10}$

Ustaški zločini koji su počinjeni nad Srbima već prvih dana nakon uspostave NDH rezultirali su mnogobrojnim odlascima Srba u partizane. Ispitanica D. K. iz Kusonja kraj Pakraca (rođ. 1961.) govori kako je "izuzetno važna bila partizanska slava koja se obilježavala svake godine u selu budući je 1942. godine izvršen pokolj u kojem je stradalo mnogo stanovnika." Ili primjer mladog ispitanika koji kaže: "Za Jasenovac sam znao od najranijih dana ..." (M. I., rođ. 1986.).

Koncentracioni logori i logori smrti kao i mjesta masovnih smaknuća i danas predstavljaju mjesta kolektivne memorije Srba i Roma u Hrvatskoj. Kao što je uočljivo na osnovi stvarno proživljenog, a u većini slučajeva na osnovi sjećanja prenesenog i oživljenog kroz transgeneracijsku perspektivu gdje su uvijek iznova konstruira pitanje žrtve (vlastitog naroda) i zločinca (kolektivna krivnja svih Hrvata), nosioci takvoga traumatičnog kolektivnog sjećanja iskazuju snažnu moralnu obvezu prema predcima kroz svjesni napor da se takva nepravda nikada ne zaboravi. Slični mitsko-konstruktivistički

\footnotetext{
${ }^{9} \mathrm{O}$ toj temi podrobnije piše Škiljan (2014a).

${ }^{10}$ www.jusp-jasenovac.hr
} 
pojam nacije susrećemo među mladim potomcima hrvatskih iseljenika na primjeru obilježavanja komemoracije Bleiburga (Perić Kaselj 2014). Mitovi prošlosti oblikuju etničku/nacionalnu zajednicu i na taj način postaju žarište u oblikovanju nacije (Dugandžija 1999). Prepričavanjem mitova dolazi do obnavljanja etničke zajednice. Povratak u prošlost vrlo je bitan za održavanje zajednice u sadašnjosti.

Kazivačica M. S. iz Velikih Grabičana pokraj Koprivnice (rođ. 1986.) priča o svojem djedu koji je ostao bez svojeg oca koji je ubijen u Jasenovcu, što je ostavilo pečat na cijeli njegov život: "Djed je ostao bez oca kad je imao pet-šest godina. Nikada poslije nije volio Hrvate, a čitav je svoj život odlazio na komemoracije u Jasenovac i Jasenovac je činio dio njegova identiteta."

I za Rome Jasenovac ima krucijalnu ulogu u kolektivnom pamćenju. Komemoraciju danas Romi obavljaju na romskom groblju u Uštici, a njihova su stradanja u odnosu na njihov predratni broj u relativnim brojkama bila svakako najveća. Često se poistovjećuje vrijeme stradanja u NDH s razdobljem Domovinskog rata u Hrvatskoj, o čemu govori i ispitanik S. Đ., Rom iz Bjelovara, rođen poslijeratne 1947. godine:

"1941. g. i 1991. g. gadno se pisalo Romima, pa ih je zato malo ostalo u Bjelovaru. Zato se 2001. nisu htjeli izjasniti kao Romi. Od mojih Đurđevića stradalo je 578 u Jasenovcu. Mi se možemo pomiriti s hrvatskim narodom, ali zaboraviti ne možemo."

O poistovjećivanju Jasenovaca i Roma i danas govore grafiti/poruke netolerancije i stigmatizacije u gradu Čakovcu, sjedištu županije s najvećim brojem Roma u Hrvatskoj, o čemu govori ispitanik M. M., Rom iz Murskog Središća, rođ. 1982.: "U Čakovcu je stajao natpis: dosta ciganskog; CiganiJasenovac, vlak bez povratka ..." Upravo će ova vrsta kolektivnog pamćenja doći do izražaja za vrijeme Domovinskog rata kada će Romi i Srbi hrvatski nacionalni identitet poistovjećivati s ustaštvom. 


\section{RASPAD SOCIJALIZMA: NACIONALNE MANJINE U PROCJEPU IZMEĐU SAMOSTALNE HRVATSKE I OČUVANJA JUGOSLAVIJE}

Raspad socijalizma najavljen je prvim višestranačkim izborima koji su u Hrvatskoj provedeni 1990. godine. Nacionalne manjine u Hrvatskoj $\mathrm{u}$ tome su se trenutku našle u vrlo nepovoljnom položaju (u područjima koja su bila etnički šarolika). Mađari, Romi, Rusini i Slovaci činili su panoptikum šarolikosti nacija istočne Slavonije, zapadnog Srijema i Baranje, a Česi, Ukrajinci i Talijani činili su taj isti panoptikum u zapadnoj Slavoniji. Uzroci nesnalaženja bili su političko djelovanje u dugogodišnjem jednopartijskom uhodanom sistemu koji je nacionalnu pripadnost kao političku kategoriju smatrao nevažnom, čak i štetnom, i svaki iskorak u tom pravcu karakterizirao kao nacionalizam i nespremnost za integraciju u jugoslavensko društvo. Nesnalaženju narodnosti u novonastaloj situaciji pridonosili su politički upravljački slojevi narodnosti koji su godinama predstavljali pojedine etničke skupine, a koji u danom trenutku nisu mogli promijeniti političke programe. Osim toga, centralna udruženja koja su uglavnom bila kulturnog karaktera, bila su najčešće smještena u susjednoj Vojvodini (kao što je slučaj kod Slovaka, Mađara, Rusina i Ukrajinaca). Posljedica toga bio je porazni rezultat na izborima na kojima nije bilo manjinske liste ni manjinskih predstavnika. Pripadnici nacionalnih manjina koji su živjeli u susjedstvu s Hrvatima uglavnom su se opredjeljivali za samostalnu Hrvatsku, dok su oni koji su živjeli zajedno sa Srbima smatrali kako je jedina opcija zajednička država Jugoslavija. Opredjeljivanje je znalo ovisiti i o konfesionalnoj pripadnosti. Tako su Romi u Baranji (koji su uglavnom pravoslavne vjeroispovijesti) ostajali uz Srbe, dok su rimokatolički Romi u Slavoniji i Međimurju pristajali uz Hrvate. Evangelici (Slovaci), kalvini (Mađari) i grkokatolici (Rusini i Ukrajinci) ostajali su u najvećem broju slučajeva uz Hrvate.

Na primjeru sela Mikluševci prikazujemo na koji su način Rusini dočekali demokratske promjene i formiranje samostalne Hrvatske. Mikluševci su 1991. godine imali 648 stanovnika, od čega je bilo 521 Rusin, 73 Srba, 44 Hrvata, 2 Ukrajinca, 1 Nijemac i 7 neopredijeljenih. Na referendumu za neovisnu Hrvatsku u Mikluševcima se oko 70\% ljudi izjasnilo za hrvatsku neovisnost. Jedan dio Rusina i Srbi izjasnili su se za 
ostanak u Jugoslaviji, a drugi dio sela opredijelio se za neovisnu Hrvatsku. Nakon zauzimanja Mikluševaca od strane JNA, iz sela su se trebali iseliti svi oni koji su ostali, a bili su na strani HDZ-a (64 kuće ili više od 150 ljudi). Štab sela nakon zauzimanja od strane JNA vodili su lokalni Srbi i Rusini. Kuće Rusina koji se iseljavaju oduzete su u ime SAO Istočne Slavonije, Baranje i zapadnog Srijema, a namjera je bila u njih naseliti Srbe iz Vukovara kojima su kuće uništene u ratu. D. M. iz sela Mikluševci izjavila je:

"Ovi naši Rusini, znate, oni su kao suncokret. Došao Tuđman na vlast, oni svi za Tuđmana, jer Tuđman je poslao svoje delegate da im obeća zemlju i kuće, dat će im novu mehanizaciju, i oni svi uz Tuđmana. Kada je Tuđman propao, i dio njegove Hrvatske, oni su sad svi za Jugoslaviju. Sada traže da ih vojska primi i da oni kažu kako oni nisu krivi, kako su lojalni građani ovoga sela. Kako koja vlast dođe, oni za nju. Samo, znate što, mi s takvima živit nećemo, ili oni ili mi. Kad mi Srbi idemo kroz selo, oni se podsmjehuju i okreću: ide Srbin ili Srpkinja. Mi to nećemo. Svi ogriješeni iz sela imaju da idu. Ili ćemo mi pozvati Gorana Hadžića da se postara za ovih 15 srpskih kuća, da nas iseli. [...] Vojska ih moli 7 dana da predaju oružje, jer će vojska bombardirat selo. Kaže Joakim Ljikar mom mužu: neka poruše, njemu će Tuđman i Vatikan napraviti novu kuću. Šta sad njegov otac hoće, on tu nema šta da traži. Otišli mu i unuk i sinovi..."

Tek 1998. godine uslijedio je povratak u Mikluševce i Petrovce. U kućama izbjeglih Rusina nalazili su se između 1993. i 1997. godine Srbi koji su bili protjerani iz područja Podravske Slatine, Slavonske Požege, Đakova, Pakraca, Vinkovaca, Slavonskog Broda, Orahovice, Karlovca, Slunja, Vukovara i Nove Gradiške (Biki 2007). U Domovinskom ratu Rusini i Ukrajinci bili su najzastupljenije nacionalne manjine u redovima Hrvatske vojske (njih 410 se nalazilo u Hrvatskoj vojsci).

\section{INTEGRALNO JUGOSLAVENSTVO}

Integralno jugoslavenstvo svojevrsni je političko-ideološki konstrukt koji je označavao jedinstvenost jugoslavenske nacije naspram etničke/ nacionalne posebnosti naroda koji su živjeli na teritoriju Jugoslavije. 
Kategorija Jugoslaven službeno je uvedena u popis stanovništva tek u trećem poslijeratnom popisu stanovništva 1961. godine i označavala je stanovnike koji se nisu opredijelili ni za jedan određeni identitet (Petrović 1983). U razdoblju od 1961. do 1981. godine u svim dijelovima bivše Jugoslavije porastao je broj onih koji su se opredijelili kao Jugoslaveni. U Hrvatskoj se 1961. godine 1,9\% stanovnika izjasnilo kao Jugoslaveni, a 1981. godine bilo ih je 8,2\%., dok je 1991. godine, uoči raspada Jugoslavije i rata, taj udio pao na 2,2\% (Sekulić 1997). Takav drastičan pad rezultat je nacionalnih sukoba i raspada jugoslavenske države. Glavne razloge izjašnjavanja Jugoslavenima Sekulić (2001) nalazi u sljedećim faktorima: 1. položaj manjine - manjine su izbjegavale svoj manjinski položaj izjašnjavajući se kao Jugoslaveni (univerzalističke ideologije ih izdižu iz manjinskog statusa); 2. demografski - djeca iz mješovitih brakova, kako bi izbjegli izbor između dvije nacionalnosti, odlučivali su se za jugoslavenstvo; 3. politički čimbenik - članstvo u partijskim i drugim društvenim organizacijama spontano je vodio jugoslavenstvu; 4. modernizacijski čimbenik - mlađi i urbaniji ljudi bili su skloni jugoslavenstvu; 5. manji dio je time protestirao protiv etničkog nacionalizma (Sekulić 2003:153). Izjašnjavanje za jugoslavenstvo, kako navodi Sekulić (2003:153), vjerojatno se nije temeljilo samo na "pozitivnoj" identifikaciji s jugoslavenstvom nego je bilo i rezultat "negativne" identifikacije s tradicionalnim nacionalizmom i njegovom ulogom u jugoslavenskoj politici.

Pojedine čimbenike Sekulićevih teorijskih razmatranja potvrđuju i sljedeći primjeri naših ispitanika. Opredjeljenje za jugoslavenstvo djece iz mješovitih brakova, a potom na "uvjetovanost" na etnički izbor nakon raspada Jugoslavije pokazujemo na sljedećim primjerima:

"Bila sam Jugoslavenka jer mi je otac Nijemac, a mama Srpkinja. Dakle, prvo Jugoslavenka, a potom Baranjka. Države koju volim više nije bilo, pa sam odlučila da ću biti Njemica." (J. Š., rođ. 1955., Beli Manastir)

B. M., također Nijemac, rođ. 1956., iz Širene, smatrao je ispravnim kako je "najbezbolnije prihvatiti naciju države u kojoj si rođen" pa je tako do 1989. godine bio Jugoslaven. Demokratskim promjenama koje su uslijedile ponovno je postao Nijemac. Njegovi su roditelji za vrijeme rata 
ostali u Baranji, ali su kao Nijemci doživljavali neugodnosti te su trebali biti deložirani, odnosno prisilno iseljeni. Štitili su ih srpski susjedi. Mlađi i urbaniji stanovnici pristajali su uz jugoslavenstvo, te nisu ni smatrali bitnim razlike u nacijama i konfesijama. Ispitanik iz Knina koji je u vrijeme početka ratnih sukoba imao 12 godina bio je prije ratnih zbivanja, kao i čitava njegova obitelj, nacionalno opredijeljen kao Jugoslaven(i):

"Do početka rata nisam imao svijest o kategoriji nacionalnost. Tek sam tada čuo da se ljudi u mojoj okolici dijele na Srbe, Hrvate i druge nacije. U našoj kući krsna slava se slavila sve vrijeme (i u vrijeme socijalizma), bili smo jedina kuća u širem susjedstvu koja je to činila, ali ni u jednom trenutku nije isticano da smo mi Srbi. Znao sam samo da postoji konfesionalna razlika." (M. S., rođ. 1979., Knin)

Ispitanik (M. H., Zagreb), nastanjen u Varaždinu i rođen 1940. godine, ističe kako do 1990. godine nitko nije pitao tko si (misli na etničku/ nacionalnu pripadnost) i to je smatrao blagodatima jugoslavenskog sistema kao i pripadnosti jugoslavenskoj državi u kojoj su svi, koji su to željeli, mogli nacionalno i ideološki biti samo Jugoslaveni:

"To je bila prednost bratstva i jedinstva. Kad je došla demokracija onda smo se morali opredijeliti. To je bio šok za moju djecu koja nisu bila nacionalno usmjeravana. Jednostavno to nije bila tema. Budući da smo u Hrvatskoj živjeli poput otoka [misli na činjenicu da su kod kuće govorili slovenski jezik, (op. a.) bez da smo se javno deklarirali nismo imali potrebe izraziti nacionalnost. Ja i kolegica koji smo zajedno radili u školi smo se tek tada prepoznali kao Slovenci, odnosno tek smo u novoj državi doznali tko nam je sunarodnjak."

Ispitanica O. P., rođena u Ljubljani 1941., a koja živi u Varaždinu, također ističe kako je došlo do promijene i naglašavanja etničkog/ nacionalnog identiteta među nacionalnim manjinama raspadom SFRJ:

"Nakon raspada Jugoslavije rekla sam da sam Slovenka. I prije toga osjećala sam se ponosnom što sam Slovenka jer Slovenci su, znate, radišni i vrijedni. A danas - moj me sin pita, a kaj će ti da si Slovenka?" 
Kako je vidljivo iz navedenih primjera, jugoslavenstvo kao izraz modernizacijske, manjinske ili demografske (mješoviti brakovi) situacije nestaje raspadom jugoslavenske države koju je pratio i nestanak jugoslavenstva kao konstruirane nacionalne kategorije.

\section{DOMOVINSKI RAT: NACIONALNO/ETNIČKO NAČELO PO KRITERIJU TKO JE (U RATU) BIO NA ČIJOJ STRANI}

Nacionalni identitet kao i svi oblici društvenog identiteta sastavljeni su od kompleksne konfiguracije. Uvijek je to spona različitih udjela individualnog i kolektivnog u cijelom spektru prošlih, doživljenih, naučenih, pripisanih značenja čija se struktura mijenja pod utjecajem vanjskih čimbenika. Domovinski rat koji karakterizira specifično ratno i traumatsko stanje, prisilno premještanje stanovništva, buktanje nacionalizma i brojni drugi procesi dovodi i do redefinicije identiteta pripadnika nacionalnih manjinskih zajednica koji su živjeli na tom prostoru. Izdvojit ćemo primjer iz Baranje, općina Beli Manastir, kao multikulturne i multinacionalne sredine koja je 1991. godine brojila 22740 Hrvata, 13851 Srba, 8956 Mađara i 8718 ostalih, među kojima i 433 Nijemaca i 381 Roma (Popis stanovništva 1991, 48-49). Godine 1991. općina Beli Manastir izdvojila se iz Republike Hrvatske i priključila SAO Istočnoj Slavoniji, Baranji i zapadnom Srijemu unutar kojeg su se nalazile i čitava općina Vukovar, te dijelovi nekadašnjih općina Vinkovci i Osijek. Kako se to područje geografski oslanjalo direktno na susjednu Srbiju, bilo je ekonomski i politički vezano uz srpski teritorij. Raspadom Jugoslavije pripadnici nacionalnih manjina bili su u situaciji izbora ostanka u Baranji koja je bila pod srpskom vlašću ili prijeći na teritorij pod kontrolom hrvatskih vlasti. Prema riječima B. P., iz Bolmana, rođ. 1961., jednog od predstavnika Roma za područje Belog Manastira, za vrijeme Domovinskog rata u Baranji su u 99\% slučajeva Romi ostali u svojim kućama i do tada su se uglavnom osjećali i opredjeljivali kao Jugoslaveni:

"Kud' smo mogli otići kad je počeo rat? U crnu zemlju ne možeš, a kud god kreneš patit ćeš za Baranjom i svojom kućom. A moram iskreno da Vam kažem, Romi su se ovdje osjećali Jugoslavenima i, opet Vam iskreno govorim, te 1991. mi smo se prepali hrvatske vlasti 
u kojoj smo vidjeli nastavak ustaškog režima koji je poklao hiljade i hiljade Roma iz ovih krajeva. Onda smo računali da je bolje ostati u nekakvoj Jugoslaviji."

O prilikama nakon Domovinskog rata i položaju romske manjine saznajemo iz razgovora ispitanika. Prema njihovim riječima, nakon završetka rata Romi su, prije svega zato što su ostali u svojim kućama i nisu napustili Baranju, optuženi od strane Mađara i Hrvata za suradnju sa Srbima. Pri tomu su isticali kako su Romi bili najbolji ratnici u srpskoj vojsci te da su pljačkali napuštena hrvatska sela u Baranji. U mađarskom selu Vardarcu na romsko naselje bačena je bomba, a u više navrata razvojačeni branitelji pucali su na kuće vardaračkih Roma. Nakon tih događaja velik je broj Roma otišao iz Baranje u Srbiju ili u zapadne zemlje. Jedan dio izbjeglih Roma vratio se nakon nekoliko godina. O položaju Roma u Baranji kasnih devedesetih godina govore izjave Roma reporterima Feral Tribunea (1999) ${ }^{11}$ objavljene u članku Dom za bežanje 31. kolovoza 1999. na stranici br. 4. Zoran Mitrović iz Torjanaca:

"Koja god vlast dođe, udari po nama Ciganima. Najbolje nam je, burazeru, bilo u ono vrijeme dok je Tito hodao po zemlji, a poslije toga jebe nas ko god naiđe. Počeo rat, došla srpska vlast i odma’ nas sve mobiliziralo. Ne pita Srbin 'oćeš li u rat ili nećeš, nego moraš ili ode glava. Ako nisi za pušku, jesi za kopanje, pa ti kopaš, a on drži pušku uperenu u leđa. Pa ti budi junak i nemoj kopat'. Eto, takvi smo ti mi bili četnici."

Činjenica da su Romi u Torjancima rimokatolici stvarala im je dodatnih problema. Vlado Palko iz Torjanaca opisuje to ovim riječima:

"E, pazi sad: mi smo, kao, četnici, a pravi su nas četnici smatrali ustašama, jer smo mi Romi iz Torjanaca po vjeri katolici. Romi u Baranji su pristupali onoj crkvi koja je u nekom selu bila jača, pa smo tako ovdje uzeli katoličku vjeru. Otkad su se Hrvati vratili u selo, župnik više neće da krsti našu djecu, pa moramo tražiti veze kod svećenika u Osijeku. Ne može nam jedino zabraniti da dolazimo

${ }^{11}$ Feral Tribune, "Dom za bežanje", 31. kolovoza 1999:4. 
u crkvu, ali nas i tu ponižava govoreći na misi 'Dođite bliže, Cigani moji.' Ustašama nas smatraju i rođaci koji su otišli u Jugoslaviju."12

O položaju Nijemaca u Baranji govori J. Š., rođ. 1955., iz Belog Manastira:

"Kada je Njemačka priznala Hrvatsku bila sam 4 puta na listi za otkaz. Ali, kako je tata bio ugledan građanin Belog Manastira, imala sam ljude koji su me čuvali. Svaki od nesrba imao je jednog Srbina koji ga je čuvao. Nakon mirne reintegracije 1997. godine dobila sam otkaz zato što sam bila nehrvatica i zato što sam ostala za vrijeme srpske vlasti."

Svjedočenje J. M., predsjednika SKPD "Ljudevit Štur" upućuje na položaj Slovaka za vrijeme Domovinskog rata:

“Konvoj iz Iloka krenuo je 17. listopada 1991. god. Bilo je u njemu oko 7000 ljudi. Prva mobilizacija onih koji su ostali u Iloku, bila je već u studenom, iako je vojska jamčila da oni koji u Iloku budu ostali, neće biti mobilizirani. Osim nas Slovaka, ostalo je u Iloku dosta Hrvata koji su također bili mobilizirani, no prvi strah smo doživjeli još istog dana kad je vojska sa svojim jedinicama ulazila u grad. [...] Osim Slovačkoga veleposlanstva u to vrijeme veliku su nam podršku pružili vojvođanski Slovaci, kao i Matica slovačka u Jugoslaviji. Matica slovačka iz Vojvodine organizirala je 1992. god. pomoć u hrani i u odjeći za Slovake u Iloku. Prvi kamion s pomoći stigao je u travnju. Nakon toga je svaki tjedan stizao po jedan kamion. U prvim tjednima dijelili smo pomoć samo Slovacima, no počeli su dolaziti i Hrvati koji također nisu imali od čega živjeti, niti od koga što dobiti. [...] Nakon Bljeska i Oluje 1995., bilo nam je najteže. Pokupili su nas u radne logore i činili s nama što su htjeli. [...] Godine 1995. potpisan je Dejtonski dogovor, a nakon toga i Erdutski dogovor. Počeli su nas puštati kući ... Godine 1996. bilo je već lakše. [...] Neki su odlazili na slobodna područja Hrvatske kako bi se sreli s obiteljima. Neki od njih nisu se vidjeli pet ili šest godina." (Kuric 2002:123-125)

\footnotetext{
${ }^{12}$ http://www.aimpress.ch/dyn/pubs/archive/data/199908/90831-002-pubs-zag.htm.
} 


\section{STIGMATIZACIJA NA OSNOVI KONFESIONALNOG: MUSLIMANSKO-HRVATSKI RAT U BOSNI ${ }^{13}$}

Demokratske promjene koje su uslijedile početkom devedesetih uvelike su promijenile položaj Muslimana u Hrvatskoj. Predstavnik Bošnjačke nacionalne zajednice za Primorsko-goransku županiju I. R., Šturlić, rođ. 1956., smatra kako je Bošnjacima u Jugoslaviji bilo dobro te da su prihvaćali državni okvir u suživotu s drugim narodima Jugoslavije. Prisjeća se kako su uspostavom neovisne Hrvatske Muslimani bili isprva favorizirani od hrvatskih političara:

"Kao, evo mi smo dio zajedničkog političkog korpusa. Previše su očekivali da mi ne budemo mi nego da budemo oni, a oni nisu smatrali da su oni mi. Hrvatski politički korpus nije nas želio priznati kao zasebnu naciju. Podržavali smo obranu Republike Hrvatske i odazivali se u najvećem postotku, više nego većinski narod. Odnos prema Muslimanima se promijenio u srpnju i kolovozu 1992. godine. Onoga trena kada je obrana Bosne i Hercegovine postala ozbiljna dolazi do promjene oficijelne hrvatske politike prema Muslimanima. Odnos je bio determiniran željom da se stvori Velika Hrvatska, a val terora koji su proživljavali Bošnjaci/Muslimani na području Hrvatske imao je svoj vrhunac 1993. godine."

Probleme za vrijeme hrvatsko-muslimanskog rata najviše su imali Muslimani/Bošnjaci u većim gradskim središtima kao što su Rijeka i Zagreb, a svodio se najčešće na telefonske prijetnje i otpuštanja s posla, a tek kod istaknutih pojedinaca na policijska ispitivanja i fizičke napade. Ispitanik (I. R., rođ. 1956., Šturlić) kaže:

“... tek 1993. godine razumio sam Srbe zašto su selili 1991. godine, jer su upravo Bošnjaci/Muslimani postali neželjena nacionalna manjina te 1993., baš kao što su to bili Srbi 1991."

\footnotetext{
${ }^{13}$ Bošnjačko-hrvatski sukob ili Hrvatsko-bošnjački sukob, često nazvan i rat u ratu, bio je konflikt između Republike Bosne i Hercegovine i samoproglašene Hrvatske zajednice "Herceg-Bosna", koji je trajao od 19. lipnja 1992. do 23. veljače 1994. godine.
} 
Iako Bošnjaci u vrijeme rata uglavnom nisu fizički protjerivani iz svojih kuća, oni su bili administrativno brojno reducirani. Svatko tko nije imao hrvatsko državljanstvo nije mogao biti u radnom odnosu te nije mogao sudjelovati u privatizaciji svojih poduzeća. Brojni Bošnjaci/ Muslimani migrirali su iz Hrvatske u prvim godinama rata (1991.-1993.) zbog nemogućnosti ostvarivanja stambenih prava i prava na rad. U manjim sredinama, poput Krka i Buzeta, odnos prema Bošnjacima/Muslimanima tijekom posljednjeg rata (1991. - 1995.) bio je daleko korektniji. R. K. iz Njivica na Krku zbog svojeg rođenja 1960. u Crnoj Gori (Pljevlje) osjećao se Crnogorcem do ratnih događaja početkom devedesetih prošlog stoljeća. Zbog muslimanske konfesionalnosti i odluke roditelja da se izjašnjavaju kao Bošnjaci i R. K. se izjašnjavao Bošnjakom. Do tada su ga u DINA-i gdje je radio vrijeđali kao četnika, a poslije kao muslimana. R. K. naglašava kako se u to vrijeme osjećala atmosfera koja je davala naslutiti "da bi bilo poželjno da se svatko vrati otkud je i došao". U slunjskom kraju gdje Bošnjaci čine većinu u nekoliko sela oko Rakovice i u nekim selima u blizini Cetingrada nalazimo sličnu situaciju o čemu nam govori ispitanik iz Lipovaca pokraj Slunja:

“Mojoj su kćeri u školi Hrvati govorili: 'Ti si muslimanka.' Ja sam otišao njezinu učitelju i rekao mu za taj problem. Onda mi je on rekao da što se ja bunim kada i jest Muslimanka. Ja sam njemu onda rekao: A kako bi tebi bilo da te zovem 'Ej, ti katoliče!' Zato se osjećam strancem i ovdje i u Bosni. U Bosni sam došao s drugim naglaskom i drugim registarskim oznakama. Ja Hrvatsku smatram svojom domovinom, ali ja sam ponosni Musliman i ne želim da itko ispadne manje vrijedan. Ja hoću svoje interese braniti ovdje." (F. S., rođ. 1976., Lipovac)

\section{SKRIVENI IDENTITET: NEPOŽELJNO JE BITI SRBIN I PRAVOSLAVAC}

Stvaranje hrvatske države u ratnim uvjetima proizvelo je snažnu nacionalnu identifikaciju i postojanje jednog identiteta. Nacionalnost (Hrvat) i konfesionalnost (katoličanstvo) bili su nerazdružive kategorije. Srbi (u Srbiji i u Hrvatskoj) su definirani kao Drugi, različiti, te su im obično pripisivana negativna svojstva, bilo da se o njima govorilo u kontekstu sudbine i inferiornog položaja Hrvata u Jugoslaviji ili kao izravnih krivaca za Domovinski rat (Perić Kaselj 2015). Jedna od bitnih isticanih razlika 
ovih dvaju naroda bila je i različita konfesionalna pripadnost. U vrijeme i neposredno nakon rata mnogim pripadnicima srpske nacionalne manjine bilo je lakše skriti ili prešutjeti vlastiti nacionalni identitet. $O$ tome nam svjedoče i sljedeći primjeri:

"Bilo je i djece koja su vrištala na spomen da su Srbi, i odrastanjem su shvatila taj moment diskriminacije, moment poniženja i te činjenice da se skriva, da je bio prisiljen odrasti svoj identitet i sad u nekakvim kasnim dvadesetima prilaze i pitaju kako bih se ja mogao uključiti u to. On je 15 godina bio u mimikriji, ali sad misli da bi se možda ipak trebao uključiti i da je sad moment da vrati sam sebi nešto od toga što je dosad morao zatomljivati. Jer u kućama je to i dalje postojalo, nisu roditelji doma govorili djetetu 'nisi ti Srbin', nego 'znaš mi smo Srbi ali to ne smiješ nigdje glasno reći'. I kad to netko sluša sve te godine, kad dođe u 25-e onda kaže: 'E sad bih ja to htio reći.' Do početka rata nis. (N. P., rođ. 1978., Hrvatska Kostajnica);

ili

"Možda im je lakše reći da su pravoslavci, nego da su Srbi. Srbi su loši dečki, pa im je lakše reći da su pravoslavci. To je mekša varijanta. Kad mi je jedan rekao da je pravoslavac, ja sam ga pitala: 'A jeste li Bugarin?”' (M. J., rođ. 1957., Osijek).

Ispitaniku Srbinu (J. B.rođ, 1947, Kupinovac) paroh iz Novoseljana kod Bjelovara rekao je:

"Vi biste se začudili koliko se ljudi kod mene došlo ispisati iz pravoslavne vjere, da ne budu crne ovce, da se održe ... To se uostalom vidi i u popisu stanovništva." (Škiljan 2014a)

Isključivane su i druge nacionalne manjinske zajednice pravoslavne vjeroispovijesti poput Rusa, Bugara, Makedonaca i Crnogoraca. Jedna ispitanica Ruskinja iz Ekaterinburga nastanjena u okolici Karlovca prisjeća se razdoblja neposredno prije Domovinskog rata:

"Kada je počelo 1990. došlo je do podjele na Hrvate i Srbe. Sin me je pitao da li je on Hrvat ili Srbin. Govorio je ruski i hrvatski i nije znao tko je i kako se odlučiti. Srbi su se okrenuli od mene jer mi je suprug bio Hrvat, a Hrvati su me zvali četnikinjom. Doživljavala sam raznorazne prijetnje na telefon." (T. M., rođ. 1946., Karlovac) 
Primjer Ruskinja koje su došle u Hrvatsku nakon rata pokazuje da su i u razdoblju nakon rata još uvijek vrijedili slični obrasci isključivanja ili poistovjećivanja pravoslavne konfesionalnosti s nacionalnom srpskom pripadnošću. O tome govori K. H., voditeljica knjižnice Rusina, Ukrajinaca i Rusa u Hrvatskoj:

"Ljudi su imali predrasude prema pravoslavnoj vjeroispovijesti. Mislili su ako smo pravoslavni da smo Srbi. Posebno je mnogo toga bilo za vrijeme rata. I puno puta poslije direktno su me vrijeđali [...] U nižim krugovima to je mišljenje još uvijek uvriježeno."

\section{FUNKCIJA RELIGIJE U OBRANI NACIONALNOG: SRBI U HRVATSKOJ NAKON 1990-IH}

U propitivanju teorijskih pristupa o nacionalnom identitetu obično se polazi od bitnih odrednica ili kriterija u njegovu definiranju. Rasprava obično polazi od određivanja objektivnih ili subjektivnih kriterija identiteta. Religija kao objektivni marker identiteta obično se definira kao nepromjenjiva i postojana odrednica koju pojedinac mora prihvatiti ako ne želi ostati izvan grupe. Mogli bismo reći kako u višestrukosti ljudskih identiteta religija igra važnu ulogu, te je podjednako bitna za obje vrste identiteta - osobni i društveni identitet. Posebice je značajna $\mathrm{u}$ procesu konstrukcije nacionalnog identiteta te su uglavnom religijski i etnički/nacionalni identiteti u korelaciji. U konstruiranju nacionalnog identiteta u Hrvatskoj 1990-ih religija se razumijeva kao identitetskosimbolički okvira većine stanovništva te se snažno naglašava povezanost nacionalnog i vjerskog (Črpić i Zrinščak 2010:5). Devedesetih godina prošlog stoljeća dolazi do revitalizacije religije u Hrvatskoj (pravoslavlje kod Srba i katoličanstvo kod Hrvata) kao i novoga društvenog odnosa prema religijskom u kojem ona postupno sve više ulazi u javnu sferu. Isto tako političke elite koriste identifikaciju s crkvom zbog vlastite političke legitimacije.

Buđenjem nacionalizma krajem osamdesetih i početkom devedesetih u Hrvatskoj, Srbi u obrani svoga identiteta od katoličanstva, reaktiviraju pravoslavlje, odnosno religiju stavljaju u direktnu funkciju identifikacije s nacionalnim. Ispitanica B. V., rođ. 1950., iz Vrhovina pokraj Otočca, smatra 
kako su Srbi tada ponovno počeli učiti o religiji i običajima jer su 45 godina uglavnom na njih zaboravljali. Stoga nije bilo neobično da se i starije osobe tek u to vrijeme krste:

"Brat se krstio u posljednjem ratu, a krstio je i svoju djecu. Probudio se taj duh pravoslavlja. Počeli su njegovati krsne slave. Znate, oni nisu ništa znali o tome pa su morali učiti od starijih i oživljavati to. To je zato što je onaj rat bio ideološki, a ovaj je bio nacionalni. Sve je to iniciralo vraćanje običaja.” (B. V., rođ. 1950., Vrhovine)

Kazivačica M. C., rođ 1983. iz Polače kraj Knina vezuje religiju uz sindrom rata. "Oni seljaci su tražili spas i htjeli su kroz religiju pokazati svoje srpstvo i vjeru. Uostalom to su bili obični sitni seljaci koji su se vratili svojoj vjeri i u tome su pronalazili jedini način ispoljavanja svojeg identiteta.". Religioznost je osobito bila bitna u krajevima gdje su Srbi bili u manjini. Takva je situacija u sjeverozapadnoj Hrvatskoj u kraju oko Lepavine:

"Nama je religija danas posebno bitna. Mi tražimo nešto po čemu će se vidjeti da smo mi Srbi. Bez manastira Lepavine bili bismo potpuno izgubljeni. Ipak nas je malo i vidiš da nestaje taj identitet. Ne naglo, nego sporo. Kada na primjer kažeš nekome da je neki svetac taj dan, a on ti odgovori da je to nebitno.” (M. S., rođ. 1986., Veliki Grabičani)

Ispitanik M. J. iz Čukovca, rođ. 1985., ističe važnost Lepavine za Srbe sjeverozapadne Hrvatske:

"To je najveći skup Srba u tom kraju i tamo se vide ljudi iz svih tih sela. Na Veliku Gospojinu dolaze i Hrvati ondje, kao što i Srbi odlaze na proštenje u Ludbreg." (vidi više Škiljan 2014b)

\section{NOVA NACIONALNA KATEGORIZACIJA: MUSLIMANI POSTAJU BOŠNJACI}

Godine 1961. u Bosni je bio visok postotak onih koji su se nacionalno izjašnjavali kao Jugoslaveni. Bila je to posljedica odbijanja muslimana da se poistovjete $\mathrm{s}$ dominantnim nacionalnim grupama, $\mathrm{tj}$. Srbima i Hrvatima (Ramet 1992:176-186). Na popisu 1971. godine prvi 
je put uvedena kategorija "Musliman" 14 kao nacionalnost i mnogi su se muslimanski Bosanci, koji su se prije izjašnjavali kao Jugoslaveni, izjasnili kao "Muslimani”. Nakon raspada SFRJ odlukom iz 1993. godine odbacuje se naziv Musliman i prihvaća naziv Bošnjak. Rezultat je to pomicanja bošnjačkih političkih elita od državotvorne prema nacionalnoj ideji, odnosno definiranju BiH kao jedinstvene tronacionalne zajednice svih njezinih naroda. ${ }^{15}$ Prihvaćanjem novog imena, Bošnjaci su se htjeli legitimirati pred izvanjskom silom koja je sad postala glavni konstruktor i Bosne i samog bošnjaštva (Jović 2013:14). Zbog Europe je bilo potrebno smisliti novo nacionalno ime jer "tko u Evropi nema nacionalno ime, nema ni državu [...] napuštanje muslimanske dominacije smatrano je približavanjem, ali i ustupkom Europi” (Šaćir 2012:194-195).

Prema popisu stanovništva Hrvatske iz 2011. godine, vidljivo je četveroimeno rastakanje nekadašnje jedinstvene kategorije (etničke grupe) Musliman ${ }^{16}$ u Bošnjak, Musliman, Bosanac i Hercegovac. ${ }^{17}$

$\mathrm{Na}$ koji je način provođen proces mijenjanja kategorije Musliman u Bošnjak govori nam ispitanik H. Ć. (Slatina kod Cazina, sada Buzet), aktivni član Bošnjačke nacionalne zajednice Grada Buzeta:

\footnotetext{
${ }^{14}$ Abazović ističe kako je identitet Muslimana bio kreiran spojem socijalističkog i islamskog. Islamska (vjerska) zajednica (i sama preimenovana tako da iz IVZ postane samo IZ) bila je vrlo kooperativna s vlastima, pa komunisti nisu stvarali separatne nacionalne institucije Muslimana. IZ je bila ujedno i kulturalna, identitetska, kao i vjerska organizacija te nove nacije. Autor čak tvrdi kako je Islamska zajednica "trebala fingirati kao nacionalna institucija muslimanskog naroda". Šaćir govori kako je ime Musliman bilo rezultat nužnosti prilagođavanja i namjernog forsiranja "vjerskog" imena kao imena nacije kako bi se spriječio - a ne potaknuo - ravnopravan tretman te nacije s drugima u Jugoslaviji (Jović 2013:15).

${ }^{15}$ Alija Izetbegović, bošnjački lider devedesetih godina prošlog stoljeća, prestao je biti bosansko-hercegovački, te postao primarno bošnjački lider. S te je pozicije prihvatio novi naziv jer je smatrao kako Zapad neće prihvatiti da se jedna od triju republika nazove "muslimanskom". Promjena imena nacije stoga je rezultat rata, vanjskih okolnosti, kao i političke oportunosti (Šaćir, prema Jović 2003:28).

${ }^{16} \mathrm{Na}$ popisu 1991. godine u Hrvatskoj je bilo 43369 Muslimana.

${ }^{17}$ Od toga se 31479 izjasnilo kao Bošnjaci, 7558 kao Muslimani, 2059 kao Bosanci i 75 kao Hercegovci.
} 
"Mnogi nisu razlikovali nacionalnost i vjeroispovijest. Kada smo radili popis za promjenu nacionalnosti iz Musliman u Bošnjak bilo je velikih otpora. Objašnjavali smo stanovništvu da će imati veća prava kao Bošnjaci. U to vrijeme Matični ured u Buzetu radio je prekovremeno i preko vikenda da bi se Muslimani mogli preregistrirati u Bošnjake. Nekima je bilo teško otići u Matični ured i preregistrirati se."

Ispitanik F. M. (Kosova kod Maglaja, sada Buzet) smatra kako je devedesetih godina prošlog stoljeća došlo do preispitivanja identiteta Muslimana na relaciji nacija - religija - država i nerazumijevanja novonastale situacije: "Ima ljudi koji nisu bili zainteresirani, pa su ostali ono što su bili prije." Na nerazumijevanje su nailazili Bošnjaci i kod Muslimana/Bošnjaka u Buzetu, ali i kod Muslimana/Bošnjaka u Bosni i Hercegovini. U pojedinim dijelovima Bosne i Hercegovine još je uvijek snažno zastupljena ideja o tome kako su Bošnjaci Muslimani, te da jedino to mogu biti. U zapadnoj su Bosni Bošnjacima podrijetlom iz toga dijela zemlje rođaci govorili: "Ja živim u Bosni i ja znam tko sam. Ja sam Musliman" (H. Ć., Slatina kod Cazina, sada Buzet). Bošnjacima iz srednje Bosne govorili su njihovi najbliži u Bosni: "Šta vi hoćete u Hrvatskoj? Hoćete od nas da smo Bošnjaci, a mi smo od pamtivijeka Bosanci” (F. M., Kosova kod Maglaja, sada Buzet).

Jedan od naših ispitanika svoje zadržavanje i ostajanje u kategoriji Musliman objašnjava ovim riječima:

"Ako nisam Musliman nisam ništa. To je moja vjeronacija. Nisu Bošnjaci preko u Šturliću [prvo veće selo preko granice u Bosni nasuprot Bogovolji, op. a] nego su Bosanci. Mene to jako muči. Did je bio Musliman kad je Tito dozvolio da se bude Musliman. Borili smo se za to da budemo Muslimani, a Bošnjaci su bili prije 300 godina u Bosni.” (Š. K., rođ. 1977., Komesarac) 


\section{ZAKLJUČAK: UZAJAMNO PROMATRANJE U ETNIČKOJ SITUACIJI I KONSTRUKCIJA IDENTITETA}

Orijentacija i motivacija pojedinaca u "etničkoj situaciji” regulirana je spoznajnim, afektivnim i moralnim programima etničkih institucija. Ti programi proizvode i učvršćuju granice prema drugim etničkim grupama, te samim tim osnažuju etnički identitet. Spoznajni programi opskrbljuju pojedince znanjem o njima samima, znanjem o njihovoj vlastitoj skupini, o grupnom naslijeđu i povijesti (koja se katkad svodi na pojedine odabrane "aspekte prošlosti") te znanjem o vrijednostima pojedinčeve skupine. Moralni program podrazumijeva postojanje osjećaja grupnih obveza, primjerice važnosti učenja etničkog jezika, prenošenja moralnih vrijednosti skupine potomcima, endogamije te solidarnosti s članovima vlastite etničke skupine. Afektivni program etničkog identiteta "pokriva" osjećaje privrženosti grupi. Stoga se i može tvrditi da su institucije, napose etničke, tvorci i čuvari znanja koja su njihovim članovima nužna da bi opstali kao grupa (Isajiw 1988). Postojeća institucionalizirana unutarnja određenja mogu osigurati obranu od nametanja izvanjskih. Iskustvo kategoriziranja i klasificiranja može ojačati postojeći grupni identitet kroz pružanje otpora, reagiranje i ojačavanje granica.

No, i izvanjsko kategoriziranje i klasificiranje istodobno čine i bitne dimenzije unutarnjeg određenja. ${ }^{18}$ Izvanjsko određenje, ono koje drugi primjenjuju na nas, nedvojbeno ima utjecaja na naše samoodređenje (Jenkins 1996:23). Ako se kao konstitutivni čimbenik etničke situacije uzima granica između dvije etničke grupe u interakciji, tada postaje značajna selekcijska uloga institucija. Institucije su dakle selekcijski mehanizmi koji omogućuju da se jedno djelovanje nastavi na drugo, jedna komunikacija na drugu, da se nešto zapamti a nešto zaboravi. Institucije svojim kategorizirajućeklasificirajućim selekcijskim mehanizmima spajaju motive djelovanja i očekivanja te tako kroz tipiziranje ponašanja aktera u ulogama grade društvene strukture. Etničke grupe ne mogu postojati ako ne postoje i

\footnotetext{
${ }^{18}$ Proces određenja "nas" zahtijeva da se "oni”" razlikuju i time razdvoje od "nas", ili da se s "nama" kontrastiraju; grupna kategorizacija će vjerojatno teći, bar jednim dijelom, kroz pozitivno ili negativno kategoriziranje drugih.
} 
druge etničke grupe. One su prije svega posljedica dugotrajnih interakcija u etničkim situacijama. Stoga se, po Barthu (1969), etničnost može i treba definirati situacijski, što ovdje znači relacijski i transakcijski: ona se proizvodi i reproducira s ovu stranu etničke granice, na njoj i preko nje. Prema Barthu, "etničke grupe jesu kategorije pripisivanja i identificiranja kojima se služe sami akteri" (1969:10). Etničke grupe/institucije "rade" po načelu jednostavnoga binarnog kodiranja. Osnovna se operacija kodiranja provodi kroz razlikovanje na osi "mi" i “oni”, koja povlači granicu između sustava i okoline. Daljnja manipulacija "objektima" u okolini sustava prepuštena je operativnim programima izvedenim iz temeljnog koda. Iz dijalektike unutarnjih kodiranja i izvanjskih opisivanja razvija se identitet etničkih skupina. Izvanjski opisi - u obliku zdravorazumskih, znanstvenih i ideoloških diskursa te službenih statističkih popisa - izraz su refleksivne prirode modernoga društvenog poretka koji se reproducira stvarajući različite diskurse o samome sebi. Diskursi su tijesno povezani s načinima na koji su društva strukturirana i organizirana. Oni su ti koji formiraju osobne i kolektivne identitete. Diskurs kao poredak - strukturirani sklop diskurzivnih procedura - što se u kojoj etničkoj situaciji može reći, u kojem trenutku i na kojem mjestu neki iskaz vrijedi kao istinit. Određuje što je vrijedno znanja i sjećanja, a što se može potisnuti i predati zaboravu (Foucault 2007:17-19). Nadalje, stalnom proizvođenje diskursa u modernim društvima (najčešće u pismenom obliku) svrha je razviti mehanizme uključivanja i isključivanja određenih grupa u društvenom sustavu.

Naše empirijsko istraživanje potvrdilo je početnu hipotezu o važnosti Događaja u klasificiranju i kategoriziranju etničkih i nacionalnih manjina u Republici Hrvatskoj. Pored toga, pokazalo se da je Događaj bitan za samorefleksiju etničkih i manjinskih skupina koje polazeći od njega "proizvode" vlastite identitetske diskurse i kulturu sjećanja. Jednom razvijena kultura sjećanja veoma se uspješno, kako je pokazalo istraživanje, prenosi od generacije do generacije pripadnika etničkih/manjinskih grupa. Kultura sjećanja moćno je oružje u borbi etničkih/nacionalnih manjina za očuvanje svoje posebnosti u promjenjivim i nepovoljnim etničkim situacijama. 


\section{EVENT AND ETHNIC SITUATION: CHANGES TO THE IDENTITY OF NATIONAL MINORITY COMMUNITIES IN THE REPUBLIC OF CROATIA \\ (Translation)}

\author{
MARINA PERIĆ KASELJ \\ FILIP ŠKILJAN \\ ALEKSANDAR VUKIĆ \\ Institute for Migration and Ethnic Studies \\ 10000 Zagreb, Trg Stjepana Radića 3
}

DOI: $10.17234 /$ SEC.27.1

Original scientific paper

Received: 1 March 2015

Accepted: 24 June 2015

This paper presents research results concerning the (re)-construction of the ethnic / national identities of particular minority communities in the Republic of Croatia, as shaped by fluctuations in the social and historical context (over the period when Croatia was part of the Federal Republic of Yugoslavia, thereafter in the periods of democratic transformation, the Homeland War, and the independent Republic of Croatia). We take a multi-method approach, on the one hand exploring the official categorization and classification of national minorities within the Constitution of the FRY and the Constitution of the RC, whilst also examining theoretical and conceptual explanations and their implementation in defining identity. The empirical part includes in-depth interviews with members of different ethnic minority communities living across the territory of present-day Croatia. The paper emphasizes how certain institutional classificatory schemes or historical moments may be imposed or lead to volatility as concerns the strategies, positions and roles of certain minority communities. In addition to the official definition and institutionalized classificatory schemes that are directly attributed to the specific identity characteristics of each group, social identities can be the result of free choice, coercion, strategy games played by individuals / members of certain groups themselves or resources mobilized in order to achieve political or economic goals. Through considering these two approaches to the analysis of national minority identities in present-day Croatia, we elaborate not only the procedural and dynamic character of identity but also its variable and situational nature.

Keywords: ethnic situation, event, identity, ethnic group, national minority, national minorities in Croatia

\section{INTRODUCTION}

Interaction and coexistence of the majority and minority peoples, constant migrations, change of borders and socio-political systems, as well as occasional war conflicts, are an idiosyncrasy of the Croatian geography 
and history. The authors believe that the Croatian geography and history in near 'laboratory' environment provide researchers with the opportunity to find answers to some debatable theoretical questions on ethnic identity. Our work, epistemologically speaking, is founded upon Luhmann's (2001b) principle of constructing and maintaining a system by observation operation through differentiation and denomination. The result thereof is the fundamental research program (method) of systemic approach. In this theoretical framework, transformations of identity of ethnic groups are not a consequence of cultural differences between them, but rather a cognitive process in which observers produce diversity by differentiating (Bateson 1979:99).

Another research program is the observation of observers and their differentiation codes, descriptions, categorizations and classification systems. This makes understandable the mechanisms used by observation apparatuses in power to define ethnic situations and the processes behind the 'microphysics of power' manifested in ethnic situations:

"Observers do frequently better foresee an effect based on knowing a situation than a personality and, accordingly, their observation is often, if not predominantly, inconsistent with the mental state of actor." (Luhmann 2001a:240)

In this sense, our approach is also founded on the observation of parts of state and its institutions on the one side, and analysis of the discourse of minority communities in Croatia resulting from the observation and understanding of one's own position in an ethnic situation, on the other side. It is in this sense that the principal researching method of a sociologist, historian or anthropologist should be interpretive. To support this, as Geertz demonstrated earlier (1973), social sciences should not deal with 'objective facts', but rather with interpretations of these facts and interpretations of their interpretations. This, furthermore, is the last recourse of the second-, third- and $\mathrm{n}^{\text {th }}$-degree observers. From illustrated epistemological and theoretical positions, central research issue is derived: How is the basic 'inclusion-exclusion' correlation between individuals and social (primarily ethnic) groups, so inherent in the majority-minority relationship, organized within different socio-political systems? Which are the factors leading to 
mobilization, destabilization or revitalization of the multifaceted ethnic identity and what way is the identity (re)constructed in different ethnic situations?

\section{METHODOLOGICAL AND CONCEPTUAL CLARIFICATIONS}

So as to demonstrate the ways of (re)constructing the identity of given minorities within the Croatian territory, thereby testing the model of ethnic situation, this research has applied the qualitative methodological approach. Starting from a set of basic theoretical hypotheses, the research was started by an interpretive analysis of classification schemes and definitions of national minorities at the official constitutional level of both the Socialist Federal Republic of Yugoslavia (SFRY) and Republic of Croatia (RC). The empirical part of research included 50 in-depth semi-structured interviews ${ }^{1}$ of maximum variation with members of several different national minority communities residing in different places/regions within Croatia. While defining the national identity, focus was placed on such social constructs as collective memory, collective guilt and stigma leading to diverse forms of repressed, hidden, substitute or imaginary identity. This paper shows how certain institutional schematic classifications or historic Events may impose or lead to a change in strategies of self-description by an ethnic (minority) group, and are, we believe, always strongly tied to a change in ethnic situation. Besides the nature of national/ethnic identity, certain subjectiveobjective criteria potentially relevant for the clarification and definition of national/ethnic identity are also dealt with. This way elucidation is given not only to the processing and dynamic character of identity, but also its variable and situational nature. The key to the forming of identity of ethnic (national) minority communities is, hence, historic heritage. Every national community has a unique experience and history (Buzan 1991) and will, as

\footnotetext{
1 Interviews held between 2010 and 2014, according to previously agreed conditions via contacts and agreements with institutional representatives of national minorities participating in the organization of interviewee arrival and arrangement of venue. The paper lists interviewees by their initials, year of birth and place of residence.
} 
such, develop its own unique collective identity. Likewise, it was essential to determine in which period the collective identity develops, that is how much it rides on a specific ethnic situation or social, political and economic context.

When speaking of national minority identity, the concepts of ethnic/ national community and ethnic/national identity will be synonymous as they both reflect national minority communities not residing in their mother states but in the territory of the RC.

\section{ETHNIC SITUATION, EVENT AND IDENTITY OF ETHNIC GROUPS}

Ethnic situation is a theoretical and observational model enabling a specific observed ethnic situation be placed within a suitable synchronic (spatial) and diachronic (historic) context. Ethnic situation is an analytical observational tool in the eye of the observer. Observers are, according to Luhmann's constructivist epistemology, functionally differentiated social systems - science, art, politics, the law, organizations, fundamentally - the state. The present model of ethnic situation includes a spatio-temporal context covered by observation, participants-individuals (actors) and the state - the supervisory and classification apparatus with the political power. The structures and processes in an ethnic situation (this case, Croatian) are realized via uninterrupted communication and interaction. The Event builds upon the event in interaction, and statement upon the statement in communication. With time, interaction and communication become routinized, institutionalized and form relatively firm relationship structures liberating participants from thinking about what to do in each and every specific situation (Berger and Luckmann 1992:42-45). In a world of routinized events and communication, on occasion an Event takes place in the sense of A. Badiou (2005:173-178). The Event is, unlike the usual events, recognized by automatic impact on the change of ethnic situation. After it, the past or the future of participants in an ethnic situation simply cannot remain the same. A credible description of an ethnic situation presupposes observation of the function of the state as an organization concentrating power in a given territory and its roles in shaping the ethnic situation. State 
power is realized by mechanisms of observation, supervision, surveillance, nomination and categorization of social groups and individuals constituting its population. ${ }^{2}$

Examples of above Events in the Croatian ethnic situation are the Anti-Fascist (Communist) victory in WW2 or the decision to separate from the SFRY and create Croatia as a national state. The Croatian state, like any other, soon assumed its fundamental functions: population census, surveillance, penalization, legislation, all based on the new population classification scheme. Starting from Luhmann's (2001b) principle of constructing and maintaining a system by observation operation through differentiation and denomination, this research focused particularly on the (self)descriptions by observers (of the state as a classifying surveillance apparatus and members of ethnic groups) and their logical grouping into classification systems of human cooperatives, discourses, attitudes and constructions of diverse identities. ${ }^{3}$

\section{NATIONAL MINORITIES AND THEIR CONSTITUTIONAL POSITION WITHIN SFRY/RC}

The decision on building Yugoslavia on the federal principle, officially adopted in 1943 in Jajce, set forth a conclusion on the national issue on the basis of full equality of all peoples in Yugoslavia. National minorities' rights were also agreed upon, in principle. State Anti-Fascist Council for the National Liberation of Croatia (ZAVNOH) on 9 May 1944 passed the Declaration of Basic Rights of Peoples and Citizens of the Federal State of Croatia to proclaim that national minorities in Croatia will be given full rights to a national life. The Constitution of 1963 for the first time introduced the

${ }^{2}$ For a more detailed presentation of said functions of the state, see article Power of Classifications: Classification Schemes and the Construction of Ethnic Structure in Civil Croatia and Slavonia (1785-1860) (Vukić 2008).

${ }^{3}$ Writing from a somewhat different theoretical standpoint on the pivotal role of classifying and categorizing apparatuses, and on the relationship between ethnicity and nationalism in identity construction is T. H. Eriksen $(1991 ; 2002)$. 
concept of 'peoplehood' (narodnost). The provision on national minority right to freely use their language and develop their culture was now added the right to form minority organizations. The constitution also foresaw the basic rule on schools for members of given national minorities, according to which classes were to be held in the languages of national minorities. Pursuant to Article 43, the republican constitutions and legal acts were given authority to establish any other rights of individual national minorities. ${ }^{4}$ Vital changes in the status of peoples and peoplehood were introduced in the Constitution of SFRY on 21 February 1974. Only then was peoplehood integrated equally and fairly in the system, and became bearer of sovereignty within the federation itself. It was from that point on that the republican constitutions too introduced the concept of 'peoplehood', parallelly with (except in the constitutions of Bosnia and Herzegovina, and Montenegro) 'ethnic group'. Ethnic group referred to Romanies, Vlachs and Jews. Based on such status of man and citizen, primarily as member of a nation or ethnic group, the Socialist Yugoslavia formed the methodology of population census. Unlike previous censuses and classification methodologies, the Socialist Yugoslavia for the first time allowed personal attitudes toward ethnic and national belonging. Each citizen was given right to declare their affiliation with a people or nationality (Art. 170 of the Constitution of the SFRY, 1974). Regardless of their decision, the citizen enjoys full equality in rights and obligations and before the law because nationality, race, sex, language, religion, education or social status cannot be used to discriminate against somebody (Art. 154). Any encouragement or imposing of national intolerance, or stirring up of national, racial or religious hatred is held to be unconstitutional and punishable by law. Pursuant to the Constitution of 1974, Yugoslavia was envisioned as a federation of republics wherein each one (with the exception of Bosnia and Herzegovina) belonged to a single nation. Serbia comprised autonomous provinces of Vojvodina and Kosovo that were simultaneously constituents of the SFRY. Pursuant to Article 1 of the Constitution, the SFRY was defined as a state association of voluntarily united peoples with their socialist republics, plus autonomous provinces

\footnotetext{
${ }^{4}$ Constitution of the Federal People's Republic of Yugoslavia (FPRY) from 1963, Official Gazette, Belgrade, 1964.
} 
of Vojvodina and Kosovo. Nations were held to be such ethnic groups that owned their own republic/state: Croats, Serbs, Slovenes, Macedonians and Montenegrins. ${ }^{5}$ Status of a national minority, according to the Constitution of the Socialist Republic of Croatia (SRC), was granted to ethnic groups with a mother state (Czechs, Hungarians, Ruthenians, Slovaks, Italians and Ukrainians), while status of an ethnic group to peoples without a state of their own (Romanies). ${ }^{6}$

The nations within the SFRY had the status of 'constitutive people', pillars of the federation. Members of the nations also had certain advantages in the whole territory of the country. Serbs, pursuant to the Constitution of the SRC, were a constitutive people of the Republic up until the Constitution of 1990 made them equal with all other national groups. One of key determinants of the equality of national minorities within the SRC was their direct participation in representative bodies and state administration on all levels.

The concept of minority was not introduced until the Constitution of the Republic of Croatia of 22 December 1990. The Constitution of 1990 and Constitutional Act on Human Rights and Liberties and Rights of Ethnic and National Communities or Minorities (1991) list sixteen minority groups or communities, seven mentioned above (Czechs, Hungarians, Ruthenians, Slovaks, Italians, Ukrainians and Romanies), five minority communities formed from the former constitutive peoples of the then Yugoslavia (Montenegrins, Macedonians, Muslims, Slovenes and Serbs) plus groups who for political (Austrians and Germans) or other reasons (Jews, Albanians) were not accepted by the former system as national units on the Croatian territory.

5 Muslims had the status of 'constitutive people', a nation, but their position was by far different due to the fact that they had no republic/state of their own.

${ }^{6}$ Albanians, though a recognized minority in Yugoslavia, did not enjoy the same status in Croatia within the SFRY; Jews, due to non-diversification of the religious and the national, had no constitutionally guaranteed minority rights; Austrians and Germans, on account of collective guilt, had no right to self-organization; while the Russians, Bulgarians, Greeks, Turks, Vlachs, Poles and Romanians, because of their fewness and disinterest, remained but an occasional phenomenon in Croatia. 
In keeping with the Constitutional Act on Amendments to the Constitution of the Republic of Croatia (1997), the original core of the Constitution listed the following autochthonous minorities ${ }^{7}$ in Croatia: Serbs, Czechs, Slovaks, Italians, Hungarians, Jews, Germans, Austrians, Ukrainians, Ruthenians and others, but not Slovenes or Bosniaks. After protests and pressure exerted by the EU, the Constitutional Act on Human Rights and Liberties and Rights of Ethnic and National Communities or Minorities in the Republic of Croatia of 2000 (consolidated text) acknowledged the status of national minority to virtually all ethnic groups, including Slovenes and Bosniaks (Art. 3). The same article lists the following national minorities whose equality is protected by the Republic of Croatia, namely Albanians, Austrians, Bosniaks, Bulgarians, Montenegrins, Czechs, Hungarians, Macedonians, Germans, Poles, Romanies, Romanians, Ruthenians, Russians, Slovaks, Slovenes, Serbs, Italians, Turks, Ukrainians, Vlachs and Jews.

The above solution of recognizing equal rights to all ethnic minorities regardless of their number or duration of stay within the territory of the state was a positive legislative precedent on the Croatian part. For comparative purposes, no legal acts by European countries recognize Romanies as a national minority. Particularly revolutionary was, thus, the decision on recognizing the status of national minority to Albanians arriving in Croatia as the migrant workforce. On the day of 13 December 2003, Croatia fulfilled one of the pivotal prerequisites for the accession to the European Union by adopting the Constitutional Act on the Rights of National Minorities, thus laying the legislative and political ground for uninterrupted growth of minority communities. The framework of the new Constitutional Act was taken from international conventions and acts Croatia is signatory to that are based on the pivotal constructs of multiculturalism and peaceful coexistence.

\footnotetext{
7 The concept of autochthonous minorities implied only minorities who had previously been residing in a country for over one hundred years. This notion was, fortunately, later dropped for being rather dubious and Bosniaks were eventually granted minority status. For more on the ideological aspects of term 'autochthonous', see article by Irena Šumi and Alenka Janko Spreizer (2011:101-121).
} 


\section{DEFINING THE NATIONAL (ETHNIC) IDENTITY: CHOICE, COERCION OR SOMETHING ELSE?}

Definition of one's identity by members of a certain national minority community can be contingent on various historic, political or other factors. Through different examples of national minorities, it will be shown that ethnic (national) identity is a 'product' of ethnic situation in which ethnic groups and individuals apply primordial, instrumentalist and constructivist strategies so as to define the situation in conjunction with other ethnic groups.

It is these 'primordial'8 determinants of identity, as first used by Shils (1957), that were the foundation of maintaining primary groups and connective tissue of integration and reproduction of global society. According to Geertz (1963), primordiality is a cultural fact implying solidarity characterized by sense of closeness (blood ties, religion, language...). Primordial determinants of the identity of ethnic groups are a 'given' base for building the identity of individuals, members of ethnic groups. Construction of identity or self-descriptions produced continuously by individuals or ethnic groups cannot come from thin air or arbitrarily, for that matter. The reality of the world and ethnic situation is socially constructed as a result of implicit work of social institutions, while ethnic institutions are, according to Mary Douglas, by definition, primordial - zero institutions (Douglas 2001).

Ethnic identity may also be utilized instrumentally as a resource subjectable to mobilization in winning political authority and economic wealth. Glazer and Moynihan (1975:18) stress these as forms of identification based on different realities such as religion, language or national origin, sharing a common "fact of having become effective foci of group mobilization for concrete political goals". Ethnicity stimulates group solidarity and veils specific common interests fought for. (Cohen 1969). Ethnic groups are defined as instrumental groups, artificially

\footnotetext{
${ }^{8}$ An exceptional debate on the primordial - instrumentalist correlation in the construction of ethnic identity can be found in a book by Irena Šumi: Kultura, etničnost, mejnost.
} 
created and maintained for their pragmatic utility (Vincent 1974). It has been demonstrated that, according to quoted authors, ethnic identity may be utilized to achieve individual goals, while in some situations it may become the means of collective (ethnic) mobilization in a struggle for power. Interactionalists have developed two streams of theoretic approach, the first of which focuses on procedures of classification and categorization to manage interaction, while the second tackles the issue of social status.

The former approach was developed in 1950s by researchers from the Rhodes-Livingstone Institute. Ethnicity is seen as a dynamic category. Ethnic identity is defined as a cognitive framework with a pivotal role in social relationships and interpretation of certain situations. Ethnic symbols and names represent cognitive points the actors resort to in order to verify the propriety of their own behavior. Categories forming one ethnic group always contrast each other. The birth of one category necessarily stimulates the onset of associated categories.

The latter approach, developed by S. M. Lyman and W. Douglass (1972), defines ethnicity as part of a situation where actors find themselves while interacting. According to the two, ethnicity appears as means of construction, manipulation and modification of reality. Contacts and interaction between the actors yield a variety of situations defining a variety of identities. This way, a situational analysis of ethnicity has to do with a study of diverse strategies by individuals (changing ethnic identity as a strategy for realizing own interests) in shaping and expressing their ethnic identity.

Constructivists (Cornell, Harman 1998) see national identity as developing and building over the course of lifetime, sometimes the result of free choice of the individual and sometimes a combination of hereditary plus predefined and newly formed identities.

The following stories exemplify how the national identity of given minorities in the Croatian territory was the result of free choice, coercion or something else. 


\section{COLLECTIVE GUILT: GERMAN STIGMA AND EXILE}

Collective guilt is a psychological experience which may or may not have real connotations of the relived; Individual group members need not participate in causing damage or injustice to another group. Collective guilt has most commonly two basic manifestations: accepting collective guilt or ascribing collective guilt. Here, the latter form, specific for the insistence of the victimized group that another group assume responsibility and collective guilt, will be discussed. Specifically, this is an example of categorizing German national minority living in the area of SRC/SFRY as the guilty party based on the crimes committed by their compatriots during WW2. By a draconic decision by the Anti-Fascist Council for the National Liberation of Yugoslavia (AVNOJ) dated 21 November 1944, all property of the Reich citizens and German nationals in the territory of Yugoslavia (with the exception of soldiers in the People's Liberation Army (NOV) units or subjects of neutral states not suspected of supporting the enemy during the war) was seized by the state (Geiger 1997:31). According to the then understanding, the "issue of Volksdeutsche in Yugoslavia should be settled once and for all" and the "state should be cleansed of minorities":

"In addition to military cleansing, other means should be applied to force national minorities to emigration. Primarily on account of their taking sides during the war, they should be deprived of all their minority rights. All minority members who placed themselves at the service of occupying forces should be roothlessly court marshalled. Concentration camps should be built for them, their properties seized, their families also sent to camps and then transferred to their national states as soon as possible." (Vasa Čubrilović, university professor at the time, author of exposé on the exile of Germans, Hungarians, Romanians and Albanians from Yugoslavia, dated 3 November 1944 for the Presidium of the People's Assembly of the People's Republic of Serbia, Beus Richemberg 2010:189)

According to testimonies by members of the German national minority, as early as in 1943 different attitudes formed towards Germans (Volksdeutsche) in Croatia, that is Yugoslavia. What used to be exemplary and hardworking neighbors were suddenly categorized as an 'unwanted criminal nation'. 
"Year 1943 was a good indicator of the final outcome of war. Those were harsh times for the Germans regardless of what kind of people they were. Whether someone was honest and kind-hearted, ideological opponent of Nazism or, simply, a woman, child or weak old man became irrelevant. It sufficed being a German to be tagged." (O. K., born 1939, Beli Manastir).

At the time, forced relocation, a somewhat of an exodus, of Germans from the SFRY/RC took place. German authorities evacuated to the West a vast number of German-origin families located in satellite states. According to own recollection, a picturesque impression of the German exile, as well as dislocation of his own family, is given by an interviewee from Beli Manastir:

"Krauts left on wagons, just like Indians in the movies, in the fall of 1944. Their left the furniture and buried the china hoping they would return. Some things they hid by partitioning cellars. When Belgrade passed the decision that all Germans were enemies, we were sent to camp. My grandparents were left in Baranja. My great grandmother and us, children, were taken to Mitvar near Grabovac for about a month. Later on, we were transferred to Đakovo. We walked there (when I saw Vukovar and the lines of people during the latest war, I saw myself). My uncle, a partisan, came for us at the camp and took us back home." (P. M., born 1933, Beli Manastir)

A large number of Germans who stayed in Yugoslavia or returned there from Germany or Austria ended up in camps all over the country. One interviewee shares his experience:

"Our family was always at the head of the line, front rows. My mother would carry my younger brother and whatever was left in one suitcase, my grandparents what they had wrapped up in a bundle, my aunt her baby boy and I walked clinging to my mother's skirt not to fall behind.” (O. K., born 1939, Beli Manastir)

Apparently, being a German in postwar SFRY/RC (whether or not one had participated in the war or had just been a baby) meant being a member of a criminal people and thus bearing stigma. The ramifications of 
collective guilt blame were devastating, among other, changes in the ethnic structure of settlements, Germans declaring themselves as Hungarians or Yugoslavs, fear of using one's own mother tongue, trauma, stigma/social exclusion, etc.

Such traumatic situation lead to repression of one's true identity and accepting what was the desirable option or existentially the only acceptable identity. The following examples speak in favor thereof:

"I was constantly tied and yelled at: Kraut! Kraut! If you had no Serbian origin, then you had big problems finding work. Me and my brother, my mother always declared as Yugoslavs. You were born in Yugoslavia and as far as that state exists, Yugoslavian you will be. When Yugoslavia ceases to exist, you will get to decide what to call yourself." (B. M., born 1956, Širine);

"I could only speak German. My mother would not let us use it. Under this social pressure my brother and I practically lost touch with the language. We picked up Hungarian and Serbo-Croatian. I was enrolled into school as a Hungarian. Being Hungarian was less awkward. At the time, there were many Hungarized Germans. I was a registered Hungarian up until the 70s, when the single L in my last name became double L.” (O. K., born 1939, Beli Manastir)

Between 1943 and 1990s, the national identity of the German minority in the region was hidden and repressed. It was not before the democratization and break-up of the SFRY that Germans started declaring themselves as such. It was then that this national minority assumed back its social visibility. ${ }^{9}$

9 For more on this topic, see Škiljan (2014a). 


\section{JASENOVAC COMMEMORATION - IMPORTANCE OF COLLECTIVE MEMORY IN FORMING NATIONAL IDENTITY}

If we opt for the individualist interpretation of collective memories, then focus will be placed on individuals as bearers of these memories. Individuals in their minds activate collective memories, and by adopting and giving significance to them, collective memories acquire use value (Kansteiner 2002). The importance of collective memories of the WW2 victims will be shown in Romanies' and Serbs' stories. The place/ monument honoring their personified memory is the Jasenovac Camp, where, according to the name list, 83,145 victims lost their lives. ${ }^{10}$

Ustashi crimes committed to Serbs ensued mere days upon founding the Independent State of Croatia (NDH), resulting in numerous Serbs joining the Partisans. Woman D.K. from Kusonje near Pakrac (born 1961) speaks about the "significance of annual partisan celebration in the village in commemoration of the mass slaughter of 1942". Another young interviewee says: "I learned about Jasenovac early on..." (M. I., born 1986).

Concentration and death camps, as well as the locations of mass executions are even today places of collective memories for both Serbs and Romanies in Croatia. As is evident from real-life experiences, and in most cases of memories recounted and relived through transgenerational perspective, which implies continual reconstruction of the issue of victim (own people) and criminal (collective guilt of all Croats), the bearers of such traumatic collective memories sense a strong moral obligation towards their ancestors through conscious effort to never let the injustice be forgotten. A similar mytho-constructivist notion of nation is encountered among young descendants of Croatian immigrants in the case of Bleiburg Commemoration (Perić Kaselj 2014). The myths of past shape an ethnic/national community thereby turning into focal points in forming a nation (Dugandžija 1999). By retelling myths, the ethnic community is restored. Going back in history is essential for keeping the community focus in the present.

Interviewee M. S. from Veliki Grabičani near Koprivnica (born 1986) recounts the story of her grandfather whose father was executed in Jasenovac. This left an irretraceable stamp on his life:

${ }^{10}$ www.jusp-jasenovac.hr 
"Grandfather lost his father when he was five or six. After that, he never liked Croats and for the rest of his life he attended Jasenovac commemorations and Jasenovac became a strong part of his identity."

Jasenovac has played a crucial role for the collective memory of Romanies too. The Romany commemoration is now honored at the Roma graveyard in Uštica and their sacrifice, in proportion with their relative prewar numbers, was by far the greatest. The times of Romany suffering during the $\mathrm{NDH}$ are often compared to the Homeland War in Croatia, as witnessed by the interviewee S. Đ., Romany from Bjelovar, born in postwar 1947:

"In 1941 and 1991, the writing was on the wall for the Romanies. This is why there are so few left in Bjelovar and why in 2001 they would not declare themselves as Romanies. Of my Đurđevići line, 578 died in Jasenovac. We may reconcile with the Croatian people, but we cannot forget."

There are graffiti/messages of intolerance and stigmatization even today in Čakovec (county center with the largest number of Romanies in Croatia) testifying to the identification of Romanies with Jasenovac. This is what interviewee M. M., Romany from Mursko Središće, born in 1982 speaks about: "Čakovec had an inscription: Enough with the Gypsies; Gypsies - Jasenovac, train with no return ..." It is precisely this type of collective memory that will reach its peak during the Homeland War, when Romanies and Serbs will identify the Croatian national identity with that of the Ustashi.

\section{BREAK OF SOCIALISM: NATIONAL MINORITIES CAUGHT BETWEEN THE CROATIAN INDEPENDENCE AND PRESERVATION OF YUGOSLAVIA}

The break of socialism was announced by the first multiparty elections held in Croatia in 1990. National minorities in Croatia found themselves in a tight spot at that moment (in ethnically heterogeneous areas). Hungarians, Romanies, Ruthenians and Slovaks made up this panoptikum of heterogeneity of nations in east Slavonia, west Srijem and Baranja, while the Czech, Ukrainians and Italians made up a similar panoptikum 
in west Slavonia. The causes of disorientation were political activity in a long-standing and well-functioning single-party system which considered nationality as an insignificant, if not detrimental, political category, and characterized every step in this direction as nationalism and failure to integrate into the Yugoslavian society. The chaos with peoplehood in the new situation was further weighted down by political leaders of the peoples who for years represented given ethnic groups but could not, at a certain point in time, change political programs. In addition to that, central associations, mostly cultural in nature, were most frequently placed in the neighboring Vojvodina (as was the case with Slovaks, Hungarians, Ruthenians and Ukrainians). The consequence was a defeat in the election that did not bring a minority list or minority representatives. Members of national minorities living as neighbors to Croats mostly opted for independent Croatia, while those living together with Serbs saw the only option in a common Yugoslavian state. Their choices were known to depend, to a point, on religious issues. The Romanies in Baranja (predominantly Eastern Orthodox), likewise, stayed true to Serbs, while Roman Catholic Romanies in Slavonia and Medimurje adhered to the Croatian side. Evangelicals (Slovaks), Calvinists (Hungarians) and Greek Catholics (Ruthenians and Ukrainians) remained, in the vast majority of cases, close to Croats.

The story of village Mikluševci shows how the Ruthenians received democratic change and the birth of independent Croatia. Mikluševci in 1991 totaled 648 inhabitants, whereof 521 Ruthenians, 73 Serbs, 44 Croats, 2 Ukrainians, 1 German and 7 undeclared. At the referendum for the Croatian independence, around $70 \%$ of Mikleuševci voters declared themselves as pro-independence. One part of Ruthenians and Serbs voted for the preservation of Yugoslavia, while another part of the village opted for independent Croatia. After the taking of Mikluševci by the Yugoslav National Army (JNA), all those who remained and voted for the Croatian Democratic Union (HDZ) (64 households or more than 150 people) had to go in exile. Village headquarters after JNA seizure was managed by local Serbs and Ruthenians. Ruthenian houses that had been evacuated were seized in the name of Serbian Autonomous District (SAO) of East Slavonia, Baranja and West Srijem with the intention of populating them with Serbs from Vukovar whose houses had been destroyed in war. D. M. from Mikluševci stated: 
"Our Ruthenians, you know, are like sunflowers. When Tuđman rose to power, they all supported him because he sent his delegates around to promise them land and houses, new mechanization. When Tuđman went down, and with him one part of his Croatia, they were suddenly pro-Yugoslavia. Now they are asking the army to take them in saying that it was not their fault, that they were loyal citizens of this village. Whoever is in power, the Ruthenians vote for them. Only, you know, we refuse to live with such folk. It's them or us. When we, Serbs, are passing down the village, they sneer at us and turn around: 'Look, there goes a Serb'. We will not have it. All who have done wrong need to go. It is either that or we shall call for Goran Hadžić to take care of the remaining 15 Serbian homes, to evacuate us. [...] The army has been pleading with them for seven days to surrender their weapons, or they will bombard the village. Joakim Ljikar says to my husband: 'Let them tear it down, Tuđman and the Vatican will build him a new house'. What is it that his father wants now, he has no right here. His grandson and sons have already left..."

It was not until 1998 that the Ruthenians came back to Mikluševci and Petrovci. The Serbs exiled from the areas of Slatina, Požega, Đakovo, Pakrac, Vinkovci, Slavonski Brod, Orahovica, Karlovac, Slunj, Vukovar and Nova Gradiška (Biki 2007) stayed in their houses between 1993 and 1997 (Biki 2007). In the Homeland War, the Ruthenians and Ukrainians were the most numerous national minorities in the lines of the Croatian Army, namely 410 of them.

\section{INTEGRAL YUGOSLAV NATIONALITY}

Integral Yugoslav nationality is a political and ideological construct depicting the uniqueness of the Yugoslav nation against the ethnic/national idiosyncrasies of the peoples populating the Yugoslav territory. Category 'Yugoslav' was not officially introduced into the census until the third postwar census of 1961, describing inhabitants who could not declare for themselves one single identity (Petrović 1983). Between 1961 and 1981, all parts of former Yugoslavia reported increased numbers of citizens declaring themselves as Yugoslav. Croatia in 1961 had 1.9\% declared Yugoslavs, 
$8.2 \%$ in 1981, while in 1991, on the eve of the fall of Yugoslavia and end of war, this share dropped to 2.2\% (Sekulic 1997). Such drastic drop is the consequence of national conflicts and break of the Yugoslavian state. The main reasons for declaring oneself a Yugoslav Sekulić (2001) finds in the following factors: 1 . minority status - minorities avoided having a minority status by declaring oneself Yugoslavian (universalist ideologies saved them from the minority status); 2. demographics - in choosing between their two nationalities, children of mixed marriages rather opted for the Yugoslavian nationality; 3. politics - membership in the Party and other social organizations leaned spontaneously towards Yugoslavian nationality; 4. modernization - younger and more urbane persons were inclined towards a Yugoslavian identity; 5. a minor share protested against ethnic nationalism (Sekulić 2003:153). Declaring oneself Yugoslav, according to Sekulić (2003:153), was probably not based solely on 'positive' identification with the Yugoslavian identity, but was also a result of 'negative' identification with traditional nationalism and its role in the Yugoslavian policy.

Certain factors of Sekulić' theoretical deliberations are substantiated by the following examples of children from mixed marriages choosing Yugoslav nationality and ethnically conditioned choice after the break of Yugoslavia: "I was a Yugoslavian woman because my father was German and mother Serbian. So, first and foremost, I am a Yugoslavian and only then Baranian. The state I loved was suddenly gone and I decided to become a declared German" (J. Š., born 1955, Beli Manastir). B. M., also German, born in 1956, from Šrena, felt it "least painful to assume the nationality of the state one was born in" and, consequently, remained a Yugoslav up until 1989. Through democratic changes that ensued, he reassumed German nationality. His parents remained in Baranja during the war, but experienced suffering on account of their German nationality and were supposed to be evicted, that is exiled. They were protected by their Serbian neighbours. Younger and more urbane inhabitants chose to declare themselves Yugoslavian and saw national and religious differences as insignificant. An interviewee from Knin who was 12 at the time of initial war conflicts, had even before the war, just like his entire family, been a declared Yugoslav:

"Before the war, I was unaware of such category as nationality. It was only then that I heard people in my surroundings were divided 
into Serbs, Croats and other nations. Family patron saint (Slava) has always been celebrated in our house (even during socialism). We were the only house to do so in the wider neighborhood, but at no time were we pointed at as Serbs. All I knew was that there was a confessionary difference.” (M. S., born 1979, Knin)

An interviewee (M. H., Zagreb) residing in Varaždin and born in 1940, points out that before 1990 nobody asked anybody who they were (implying ethnic/national identity) and he attributed that to the benefits of the Yugoslavian system and state where anybody who wanted it, could simply assume a Yugoslavian nationality and ideology:

"This was the advantage of the 'brotherhood and unity'. With the advent of democracy, one had to make a choice. It was a shock for my children who had never been nationally oriented. It just never came up. We were living in Croatia as isolated as an island [referring to the fact that at home the family spoke Slovene (author's note)] and there was no need to publicly declare our nationality. It was only then that I and a colleague of mine at the school recognized each other as Slovenes, or in other words, it was only in the new state that we learned who our nationals were."

Respondent O.P., born in Ljubljana in 1941, living in Varaždin, likewise, points out that the change and emphatic display of ethnicity/ nationality among national minorities came with the fall of SFRY:

"After the break of Yugoslavia I declared myself Slovene. Even before that I was proud to be a Slovenian woman because Slovenes are, as you know, hard-working and diligent. And today - my son asks me: Why do you need to be Slovenian?"

As the presented stories illustrate, Yugoslavian identity as an expression of modernization, minority or demographic (mixed marriages) situation disappears with the break of the Yugoslavian state and takes Yugoslavian identity as a constructed national category with it. 


\section{HOMELAND WAR: NATIONAL/ETHNIC PRINCIPLE BASED ON THE CRITERION OF WHO (IN WAR) WAS ON WHICH SIDE}

National identity, as all other forms of social identity, is a complex configuration, always a relationship between varying shares of the individual and the collective within a full spectrum of past, lived, acquired and attributed significations whose structure changes under the influence of external factors. The Homeland War, characterized by specific war and traumatic conditions, forced relocation of population, raging of nationalism and numerous other processes, led to a redefinition of the identities of the members of minority communities living in the area. A case from Baranja, municipality of Beli Manastir should be singled out as a multicultural and multinational settlement which in 1991 counted 22,740 Croats, 13,851 Serbs, 8,956 Hungarians and 8,718 others, among which 433 Germans and 381 Romanies (Census of 1991, 48-49). In 1991, the municipality of Beli Manastir exited the Republic of Croatia and joined the SAO East Slavonia, Baranja and West Srijem that included the entire municipality of Vukovar and parts of what was once municipality Vinkovci and Osijek. As, geographically, this area gravitated directly towards the neighboring Serbia, it was economically and politically associated with the Serbian territory. Following the break of Yugoslavia, members of national minorities faced a difficult choice: to remain in Baranja under Serb authority or to relocate to the territory under Croatian rule. According to B.P. from Bolman, born in 1961, a Romany representative for the area of Beli Manastir, during the Homeland War, the Romanies in Baranja in $99 \%$ of cases remained in their houses and up to that moment had mostly identified with and declared themselves as Yugoslavs:

"Where could we go when the war broke out? You cannot disappear off the face of the earth, and wherever you go you will pine after Baranja and your house. And to be honest, the Romanies felt as Yugoslavs here and, again truthfully, in 1991 we got scared at the prospect of the Croatian rule that seemed to promise a continuation of the Ustashi regime, which slaughtered thousands and thousands of Romanies from the region. So we thought it was better to stay in Yugoslavia, whatever it was."

We learn about the circumstances of the Homeland War and the position of the Roma minority from a conversation between interviewees. 
According to their recounts, after the war the Romanies were, primarily because they stayed in their homes and did not leave Baranja, accused by Hungarians and Croatians of having cooperated with Serbs, as the finest soldiers in the Serbian army, and of having pillaged deserted Croatian villages across Baranja. The Roma settlement in the Hungarian village Vardarac was bombed, and demobilized defenders on several occasions fired at the Roma houses in the village. After this, many Romanies left Baranja and moved to Serbia or the West. One part of Roma refugees returned several years later. The Romanies' position in Baranja in the late 1990s was discussed by Romany representatives in article Dom za bežanje ('Home for Fleeing') published in the Feral Tribune (1999) ${ }^{11}$ on 31 August 1999, page 4: Zoran Mitrović from Torjanci:

"Whoever rises to power, comes down hard on the Gypsies. We were better off, my brother, when Tito was alive. After that, we have been screwed over by every Tom, Dick and Harry. The war started, Serbs came to the rule and we were immediately mobilized. Serbs don't ask you nicely; It's either get in or lose your head. If you can't carry a gun, you can dig, so you dig while he holds a gun to your back. You can play the hero and refuse to dig. That's what kind of Chetniks we were."

The fact that the Romanies in Torjanci were Roman Catholic caused even further problems. Vlado Palko of Torjanci puts it in his own words:

"Watch this: While we were tagged Chetniks, the true Chetniks called us Ustashi because Romanies in Torjanci are Catholic. The Romanies in Baranja joined the predominant church in a village; Here it was the Catholic Church. Ever since Croats came back to the village, the parish priest refuses to baptize our children, so we are forced to seek connections among priests in Osijek. The only thing he can't do is to ban us from the church, but he humiliates us at mass saying: 'Come closer, my Gypsies.' We are thought to be Ustashi even by our relatives who left for Yugoslavia."12

${ }^{11}$ Feral Tribune, "Dom za bežanje" ('Home for Fleeing', allusion to the film 'Time of the Gypsies', literally translated as 'home for hanging'; translator's note), 31 August 1999:4. 12 http://www.aimpress.ch/dyn/pubs/archive/data/199908/90831-002-pubs-zag.htm. 
J. Š., born in 1955, from Beli Manastir, talks about the position of Germans in Baranja:

"After Germany acknowledged Croatia, I was to be fired on four occasions. However, as my father was a revered citizen of Beli Manastir, I had people backing me up. Each non-Serb had one Serb designated to watch over them. After peaceful reintegration in 1997, I was, eventually, fired for being a non-Croat and for staying during the Serbian rule."

A testimony by J. M., president of the Ljudevit Štur Slovak Cultural and Educational Society, warns about the Slovaks' status during the Homeland War:

"A convoy from Ilok left on 17 October 1991 with 7,000 people in it. The first mobilization of those who remained in Ilok ensued as early as in November, though the army guaranteed that whoever stayed in Ilok would not be mobilized. Except us, Slovaks, many Croats also stayed in Ilok and were likewise mobilized. The first trauma we experienced the same day when the army and its troops entered the city. [...] Besides the Slovak Embassy, at the time, we were strongly supported by the Slovaks of Vojvodina and Slovak Cultural Society in Yugoslavia. Vojvodina Slovak Cultural Society organized in 1992 help in food and clothes for the Slovaks living in Ilok. The first truck arrived in April, and, after that, continued coming on a weekly basis. In the first weeks, we gave out help only to Slovaks, but soon desperate Croats who had nobody to turn to started coming too. [...] After operations Flash and Storm in 1995, it was the worst times for us. We were brought to labor camps and they did with us what they wanted. [...] In 1995, the Dayton Agreement was signed and, subsequently, the Erdut Agreement. We were gradually released home... In 1996, the situation improved. [...] Some went to free territories to meet their families, some for the first time in five or six years." (Kuric 2002:123-125) 


\section{STIGMA OF CONFESSIONARY DENOMINATION: MUSLIM- CROATIAN WAR IN BOSNIA ${ }^{13}$}

Democratic changes that ensued in the 90s dramatically changed the position of Muslims in Croatia. A representative of the Bosniak national community for Primorje-Gorski Kotar County, I. R. from Šturlić, born 1956, thinks that Bosniaks were treated well in Yugoslavia and that they welcomed the state framework in their coexistence with other peoples of Yugoslavia. He recounts that since Croatian independence, the Muslims were at first favored by the Croatian politicians:

"We are part of the common political body. They expected too much from us not to be us but them, while they did not see themselves as us. The Croatian political body would not acknowledge us as a separate nation. We supported the defense of the $\mathrm{RC}$ and responded in higher percentage than the majority people. The relationship towards the Muslims changed in July and August 1992. From that moment when the defense of Bosnia and Herzegovina became serious, there was a visible change in the official Croatian policy towards Muslims. It was a relationship conditioned by the desire to create the Great Croatia, while the terror wave that Bosniaks/Muslims were subject to on the Croatian territory peaked in 1993."

Problems during the Croatian-Muslim War were mostly had by Muslims/Bosniaks in larger urban centers such as Rijeka and Zagreb; namely phone threats and job dismissals, or in some cases even police interrogations and physical assaults. Respondent I. R., born in 1956, Šturlić, tells his story: “... it was not until 1993 that I understood why Serbs had moved in 1991; Bosniaks/Muslims became the undesirable national minority in 1993, just like Serbs were in 1991."

Though during the war Bosniaks were not usually physically expelled from their homes, they were administratively cut in numbers. No person

\footnotetext{
13 Bosniak-Croat or Croat-Bosniak conflict, often nicknamed 'war within a war', was a conflict between the Republic of Bosnia and Herzegovina and self-proclaimed Croatian Union Herceg-Bosna, which lasted between 19 June 1992 and 23 February 1994.
} 
without Croatian citizenship could find employment or, by extension, take part in the privatization of their company. Numerous Bosniaks/Muslims migrated from Croatia during the initial years of war (1991-1993), the reason being impossibility to acquire residential or employment rights. In minor centers, such as Krk and Buzet, the relationship toward Bosniaks/ Muslims during the latest war (1991-1995) was by far more decent.

R. K. from Njivice on Krk was born in 1960 in Montenegro (Pljevlje) and had, accordingly, felt Montenegrin up until the war in early 1990s. Due to Muslim confession and his parents' decision to declare themselves Bosniaks, R. K. declared himself Bosniak too. Until then he had been insulted at DINA, where he worked, as Chetnik, later on as Muslim. R. $\mathrm{K}$. emphasizes that at that time "one could take a hint that it was better for everyone to go back to where they came from". In Slunj area, where Bosniaks made up the majority in several villages around Rakovica and near Cetingrad, a similar scenario was witnessed by an interviewee from Lipovac near Slunj:

"My daughter was told in school by Croat peers: 'You are a Muslim.' I went to see her teacher and told him about the problem. He asked what the problem was when she was, in fact, a Muslim. I told him: How would you feel being addressed: 'Hey, you, Catholic!' This is why I feel a stranger both here and in Bosnia. In Bosnia I had a different accent and different license plates. I hold Croatia my home, but I am also a proud Muslim and do not wish anyone to feel less worthy. I want to defend my interests here, in my home." (F. S., born 1976, Lipovac)

\section{HIDDEN IDENTITY: IT IS NOT POPULAR BEING A SERB AND EASTERN ORTHODOX CRISTIAN}

The birth of the Croatian state during the war yielded strong national identification and unity in a single identity. Serbs (in Serbia and Croatia) were defined as the Others, different, and were usually seen negatively, whether in the context of destiny and inferior status of Croats in Yugoslavia or direct culprits for the Homeland War (Perić Kaselj 2015). One of the vital differences emphasized between the two peoples was different confessionary denomination. At that very time and just after the war, for many members of 
the Serbian national minority, it was easier to hide or simply not mention their national identity. Here are some testimonies in favor of this:

"There were children who screamed at the mention of them being Serbian. By growing up they realized this moment of discrimination, humiliation and the fact that they had been hiding, and were forced to grow into their identity. So now, in their late 20s they approach and ask how they can get included. After 15 years of mimicry, now he feels he should maybe get involved and that now's the time to give back to himself what had to be hidden deep inside. Back home the problem still exists as parents never said to their children: 'You are not a Serb', but instead 'You know, we are Serbs but you are just not allowed to say it publicly!' And having listened to this for all these years, when you get to 25 , you go: 'Now, I want to say it!'” (N. P., born 1978, Hrvatska Kostajnica);

or

"Maybe it's easier to say that you are Orthodox than Serb. Serbs are the bad guys so it's less dangerous to say Orthodox. It's the light version. When one of them told me he was Orthodox, I asked him: 'So, you are Bulgarian?"' (M. J., born 1957, Osijek). A rector from Novoseljani in the vicinity of Bjelovar told a Serbian respondent (J.B., born 1947, Kupinovac): "You would be surprised to know how many people wanted to be excluded from the Orthodox Church, not to be black sheep, to survive... This is, after all, evident in the census." (Škiljan 2014a)

Other national minorities of Eastern Orthodox denomination have also been excluded, for example Russians, Bulgarians, Macedonians and Montenegrins. A Russian woman from Ekaterinburg, residing near Karlovac, recounts the period just before the Homeland War:

"When the events of 1990 started, Croats and Serbs were suddenly divided. My son asked me whether he was Croatian or Serbian. He spoke Russian and Croatian and didn't know who he was or how to decide. Serbs turned away from me because my husband was Croatian, while Croats called me a Chetnik. I received numerous telephone threats." (T. M., born 1946, Karlovac) 
The example of Russian women who came to Croatia after the war shows a similar pattern of exclusion and identification of Orthodox confession with the Serbian nationality even after the war, according to K. H., head of a Croatian library for Ruthenians, Ukrainians and Russians:

"People were prejudiced against the Orthodox faith. They thought that if you were Orthodox, you were automatically Serbian. And even more so during the war. Many times later, I was directly humiliated... In lower circles, this opinion still holds."

\section{FUNCTION OF RELIGION IN DEFENSE OF THE NATIONAL: SERBS IN CROATIA AFTER THE 1990S}

In deliberation of theoretical approaches to the national identity, the starting point is usually key determinants or defining criteria. The debate usually revolves around the determination of objective or subjective identity criteria. Religion as an objective identity marker is traditionally defined as an unchangeable and lasting determinant which an individual must accept if they do not wish to remain outside of the group. One might say that religion plays an important role in the multifariousness of human identities and is equally vital for both types of identity - personal and social. It is particularly significant in the process of constructing a national identity. Religious and ethnic/national identities are usually strongly correlated. In the construction of national identity in Croatia in 1990s, religion was understood as a symbolic identity framework for the majority of population, and the interconnection between the national and the religious was strongly stressed (Črpić and Zrinščak 2010:5). The 1990s saw a revitalization of religion in Croatia (Orthodox Church for Serbs and Catholic Church for Croats), as well as a new social rapport with the religious in which religion increasingly permeates the public sphere. Political elites, likewise, use identification with the Church for their own political affirmation.

The awakening of Croatian nationalism in late 1980s and early 1990s stirred up Serbs in a defense of their own identity from the Catholic Church, to reactivate the Orthodox faith. In other words, religion was placed in direct function of national identification. A woman B. V., born in 1950, from Vrhovine near Otočac, feels that Serbs at that moment started learning about 
religion and custom, as for 45 years the two were most neglected. It was not unusual to see elderly persons baptized only then and not before:

"My brother was baptized during the latest war, and he also baptized his children. The spirit of Orthodox Church had been awakened. Family patron saints were again celebrated. You know, they knew nothing about it and had to learn from the elders and relive it. It is because that war was ideological in nature, and this one national. This all encouraged a revival of custom." (B. V., born 1950, Vrhovine)

Interviewee M. C., born 1983, from Polača close to Knin, ties religion to the war syndrome:

"Those villagers were looking for salvation and attempted to show their Serbianity and their faith through religion. These were, after all, small-scale villagers returning to their faith and finding in it the only medium to express their identity."

Religiousness was above all important in areas where Serbs were a minority. This was the case in northwest Croatia in the vicinity of Lepavina:

"For us, religion is very important today. We are looking for something that distinguishes us as Serbs. Without the Lepavina Monastery, we would be lost. We are few and our identity is fading away. Not suddenly but gradually. When you say to somebody what patron saint is celebrated that day, they comment it's irrelevant." (M. S., born 1986, Veliki Grabičani)

Interviewee M. J. from Čukovec, born in 1985, stresses the significance of Lepavina for the Serbs of northwest Croatia:

"This is the largest gathering of Serbs in the area and you get to see people from all the surrounding villages. The Orthodox Assumption feast is frequented by local Croats too, just as Serbs visit the Ludbreg church festival." (for more, see Škiljan 2014b) 


\section{NEW NATIONAL CATEGORIZATION: MUSLIMS BECOME BOSNIAKS}

In 1961 Bosnia had a high percentage of inhabitants nationally declaring as Yugoslavs. This was the consequence of Muslims refusing to identify with the prevailing national groups, i.e. Serbs and Croats. (Ramet 1992:176-186). The Census of 1971 first introduced the category of 'Muslim'14 as nationality. Many Muslim Bosnians, who earlier declared themselves Yugoslavs, now opted for 'Muslim'. After the break of the SFRY, the decision of 1993 rejected the name Muslim and adopted Bosniak. The result was shifting Bosniak political elites from the state-forming to the national idea, that is, towards defining Bosnia and Herzegovina as a single tri-national union of all its peoples. ${ }^{15}$ By accepting the name, Bosniaks wanted affirmation before an external force pulling the strings on both Bosnia and Bosniakness (Jović 2013:14). To please Europe, a new national name needed to be created because "whoever in Europe lacks a national name, lacks a state. [...] abandoning Muslim domination was considered approaching, but also a concession to Europe" (Šaćir 2012:194-195).

According to the Croatian Census of 2011, a quadruple dissolution is visible of the formerly unified category (ethnic group) of 'Muslim'16 into Bosniak, Muslim, Bosnian and Herzegovinian ${ }^{17}$.

14 Abazović points out that the Muslim identity was created by merging socialism and Islam. Islamic (religious) community (renamed from IVZ to IZ) was most cooperative with the authorities, which is why the Communists did not create separate national Muslim institutions. IZ was, at the same time, a cultural, identity and religious organization of the budding nation. Author claims that the Islamic Community „was supposed to pose as a national istitution of the Muslim people“. Šacir notes that the name Muslim was a product of compromise and insistence on a 'religious' name for the name of the nation to prevent - and not encourage - an equal treatment with other Yugoslavian nations (Jović 2013:15). 15 Alija Izetbegović, Bosniak leader during 1990s, ceased being the leader of Bosnians and Herzegovinians to become primarily a Bosniak leader. From this position, he accepted the novel name because the believed that the West would not accept one of the three republics being named Muslim. The change of national name is, therefore, a result of war, external circumstances and political opportunism (Šaćir, from Jović 2003:28).

${ }^{16}$ Croatian Census of 1991 reported 43,369 Muslims.

17 Where of 31,479 declared themselves Bosniaks, 7,558 Muslims, 2,059 Bosnians and 75 Herzegovinians. 
The process of changing 'Muslim' into 'Bosniak' is explained by respondent H. Ć. (Slatina near Cazin, now Buzet), an active member of the Bosniak National Community of the City of Buzet:

"Many could not tell nationality and confession apart. When we did the list for changing the nationality from Muslim to Bosniak, opposition was strong. We had to explain to the population that they would have better rights as Bosniaks. At that time, the registrar's office in Buzet worked overtime, as well as over the weekends, so that Muslims could be reregistered as Bosniaks. Some found it difficult to go to the registrar's office and reregister."

Interviewee F. M. (Kosova near Maglaj, now Buzet) believes that in 1990s Muslim identity underwent reexamination in terms of the nation - religion - state correlation and the resulting situation caused confusion: "There were people showing no interest who remained what they had been before." Bosniaks had to face rejection by their own Muslims/Bosniaks in Buzet, as well as those in Bosnia and Herzegovina. Certain parts of Bosnia and Herzegovina still strongly defend the idea of Bosniaks being Muslims as the only identity they can take on. In west Bosnia, Bosniaks originally from that part of the country were told by their relatives: "I live in Bosnia and I know who I am. I am a Muslim." (H. Ć., Slatina near Cazin, now Buzet). Bosniaks from central Bosnia were told by their families in Bosnia: "What do you want in Croatia? You want us to be Bosniaks, and we have always been Bosnians" (F.M., Kosova near Maglaj, now Buzet).

One of our interlocutors explains his decision to stay registered in the category 'Muslim':

"I am nothing, if I am not a Muslim. This is my religion and my nation. It's not Bosniaks over there in Šturlić [the next major village across the border in Bosnia, opposite Bogovolja; author's note], it's Bosnians. I have a problem with that. My grandfather was a Muslim when Tito allowed us to be Muslims. We fought hard to be Muslims, while Bosniaks were in Bosnia 300 years ago.” (Š. K., born 1977, Komesarac) 


\section{CONCLUSION: MUTUAL PERCEPTION IN ETHNIC SITUATION AND CONSTRUCTION OF IDENTITY}

Orientation and motivation of individuals in an 'ethnic situation' is defined by cognitive, affective and moral programs of ethnic institutions. Said programs yield and reinforce the borders toward other ethnic groups, thus strengthening ethnic identity. Cognitive programs supply individuals with the knowledge about themselves, their own groups, group legacy and history (which is at times reduced to chosen 'aspects of history'), and the values of their group. A moral program implies a sense of group responsibilities, such as the importance of learning an ethnic language, passing of group moral values down to one's descendants, endogamy and solidarity with members of own ethnic group. The affective program of ethnic identity includes a sense of group affection. It can, consequently, be argued that institutions, chiefly ethnic, are the makers and keepers of knowledge so necessary to their members to survive as a group (Isajiw 1988). Existent institutionalized internal determinations may provide a defense from imposing external determinations. The experience of categorization and classification can strengthen the existing group identity through resistance, reaction and border reinforcement.

However, external categorization and classification, at the same time, make up the vital dimensions of internal determination. ${ }^{18}$ External determination, such as the others apply to us, doubtlessly has an effect on our self-determination (Jenkins 1996:23). If one takes as constitutive factor of ethnic situation a border between two ethnic groups in interaction, institutions then assume a significant selective role. Institutions are, hence, a selective mechanism making it possible for one effect to build upon another, or one instance of communication on another, for something to be remembered and something forgotten. With their categorizing/classifying selective mechanism, institutions fuse the motives of effect and expectation to build social structures through typing of actor behavior. Ethnic groups

\footnotetext{
18 Process of defining 'ourselves' requires 'them' to be different and thus separate from 'us' or to be contrasted with 'us'. Group categorization will, most likely, reflect, at least partially, a positive or negative categorization of others.
} 
cannot exist without other ethnic groups. They are, principally, a result of long-term interactions in ethnic situations. According to Barth (1969), ethnicity may and should be defined situationally, meaning here - relationally and transactionally: it is (re)produced this side of ethnic border, on it and across it. According to Barth, "ethnic groups are categories of attribution and identification used by actors themselves" (1969:10). Ethnic groups/ institutions operate on the principle of simple binary coding. The basic coding operation is realized by differentiation on the 'us' and 'them' axis, drawing a border between the system and the environment. Further manipulation with 'objects' in the system environment is left to operative programs derived from the elementary code. From the dialectic of internal coding and external descriptions, the identity of ethnic groups is developed. External descriptions - in the form of reasonable, scientific and ideological discourses and official statistical lists - are an expression of the reflexive nature of modern social order reproduced by creating different discourses about oneself. Discourse is tightly connected with the ways societies are structured and organized. Discourse forms personal and collective identities. Discourse as order - a structured system of discoursive procedures - what words are appropriate in which ethnic situation or in which moment and where an expression is held to be true. Determining factor is what is worth knowing and remembering against what can be repressed and surrendered to oblivion (Foucault 2007:17-19). Moreover, the purpose of continual production of discourse in modern societies (most commonly in writing) is to develop mechanisms of inclusion and exclusion of certain groups within the social system.

The present empirical research has confirmed the initial hypothesis on the importance of Events in the classification and categorization of ethnic and national minorities in the Republic of Croatia. Furthermore, the Event proved to be vital for self-reflection by ethnic and minority groups which, starting therefrom, 'produce' their own identity discourses and culture of remembrance. Once developed, culture of remembrance is, according to the research, highly successfully passed on from generation to generation of members of ethnic/minority groups. Culture of remembrance is a powerful tool in the fight of ethnic/national minorities to preserve their distinctiveness in changeable and inopportune ethnic situations. 


\section{REFERENCES}

BADIOU, Alain. 2005. Being and Event. London: Continuum.

BARTH, Fredrick. 1969. "Introduction". From Ethnic Groups and Boundaries: The Social Organization of Boundaries of Culture Difference, ed. Frederik Barth. Oslo: Universitets, 9-38.

BATESON, Gregory. 1979. Mind and Nature: A Necessary Unity. New York: Dutton.

BERGER, Peter L. and Thomas LUCKANN. 1992. Socijalna konstrukcija zbilje. Zagreb: Naprijed.

BEUS RICHEMBERG, Goran. 2010. Nijemci, Austrijanci i Hrvati I. Zagreb: Synopsis.

BIKI, Đuro. 2007. Rusini Mikluševaca u Domovinskom ratu 1991. Vukovar: Savez Rusina i Ukrajinaca Republike Hrvatske.

BUZAN, Barry. 1991. People, States and Fear. Harlow: Longman.

COHEN, Abner. 1974. Two dimensional Man: An Essay on the anthropology of power and symbolism in complex society. Berkeley: University of California Press.

CORNELL, Stephen and Douglas HARTMANN. 1998. Ethnicity and Race Making Identities in a Changing World. London: Sage Publications.

ČRPIĆ, Gordan and Siniša ZRINŠČAK. 2010. "Dinamičnost u stabilnosti religioznosti u Hrvatskoj 1999. i 2008. godine”. Društvena istraživanja, 1-2/105-106:3-27.

DOUGLAS, Mary. 2001. Kako institucije misle. Beograd: B92.

DUGANDŽIJA, Nikola. 1999. "Mitski pristup etničkoj i nacionalnoj zbilji”. From Etničnost i povijest, ed. Emil Heršak. Zagreb: IMIN, 39-54.

ERIKSEN, Thomas Hylland. 1991. "The cultural contexts of ethnic differences". Man, vol. 26/1:127-144. DOI: $10.2307 / 2803478$

ERIKSEN, Thomas Hylland. 2002. Ethnicity and Nationalism. London: Pluto Press.

FOUCAULT, Michel. 1976. The History of Sexuality. Harmondsworth: Penguin.

GEERTZ, Clifford, ed. 1963. Old societies, new states: The integrative revolution, primordial sentiments and civil politics in the New States. New York: The Free Press.

GEERTZ, Clifford. 1973. The Interpretation of Cultures. New York: Basic Books,

GEIGER, Vladimir. 1997. Nestanak folksdojčera, Zagreb: Nova stvarnost.

ISAJIW, Wsevolod. 1988. "Ethnic identity retention”. From Ethnic Identity and Equality, ed. Raymond Breton et al. Toronto: University of Toronto Press, 34-91.

JENKINS, Richard. 1996. Social Identity. London: Routledge.

JOVIĆ, Dejan. 2013. "Identitet Bošnjaka/Muslimana”. Politička misao, 50/4:132-159.

KANSTEINER, Wulf. 2002. "Finding Meaning in Memory: A methodological Critique of Collective Memory Studies". History and Theory, vol. 41/2:179-197. DOI: $10.1111 / 0018-2656.00198$ 
LUHMANN, Niklas. 2001a. Društveni sistemi. Sremski Karlovci - Novi Sad: Izdavačka knjižarnica Zorana Stojanovića.

LUHMANN, Niklas. 2001b. Znanost društva. Zagreb: Politička kultura.

LYMAN, Stanford M. and William A. DOUGLAS. 1972. "Ethnicity: Strategies of collective and individual impression management". Social Research, vol. 40:344365

PERIĆ KASELJ, Marina. 2014. "Dijasporske zajednice u kiber prostoru: virtualni identiteti hrvatskih etničkih zajednica u Čileu i Argentini”. Studia ethnologica Croatica, 26:91-119. DOI: 10.17234/SEC.26.5

PERIĆ KASELJ, Marina. 2015. "Dijaspora i Domovinski rat: koncepti domovine i identiteti iseljenika i potomaka iseljenika". From Zbornik radova Identitet, simboli, Domovinski rat, [in publication].

PETROVIĆ, Ruža. 1983. "The National Composition of the Population”. Yugoslav Survey, vol. 24/3:21-34.

RAMET, Sabrina P. 1992. Nationalism and Federalism in Yugoslavia. Bloomington/ Indianapolis: Indiana University Press.

SEKULIĆ, Duško. 1997. "Nations and National Conflict in Successor States of former Yugoslavia”. From Race, Ethnicity and Gender. A Global Perspective, ed. Samuel P. Oliner, Phillip T. Gay. Iowa: Kendall/Hunt Publishing Company, 91-118.

SEKULIĆ, Duško. 2003. “Građanski i etnički identitet: slučaj Hrvatske”. Politička misao, 11/2:140-166.

SHILS, Edward. 1957. "Primordial, Personal. Sacred and Civil Ties". British Journal of Sociology, vol. 8/2. DOI: 10.2307/587365

ŠAĆIR, Filandra. 1998. Bošnjačka politika u XX. stoljeću. Sarajevo: Sejtarija.

ŠKILJAN, Filip. 2014a. "Nacionalne manjine u hrvatskoj Baranji između čekića i nakovnja-slučaj baranjskih Nijemaca". From Srpsko-hrvatski politički odnosi u 20. veku-zaštita identiteta. Novi Sad: Centar za istoriju, demokratiju i pomirenje, Udruga za povijest, suradnju i pomirenje-Golubić.

ŠKILJAN, Filip. 2014b. “Identitet Srba u Hrvatskoj”. Politička misao, 51/2:111-134.

ŠUMI, Irena and Alenka JANKO SPREIZER. 2011. "That Which Soils the Nation's Body: Discriminatory Discourse of Slovenian Academics on the Romany, Foreigners and Women”. Anthropological Notebooks, vol. 17/3:101-121.

ŠUMI, Irena. 2000. Kultura, etničnost, mejnost: konstrukcije različnostiv antropološki presoji. Ljubljana: Založba ZRC.

VINCENT, Joan. 1974. “The Structure of Ethnicity”. Human Organization, vol. 33/4:375379. DOI: $10.17730 /$ humo.33.4.2k101667117p4513 
VUKIĆ, Aleksandar. 2008. "Moć klasifikacije: klasifikacijske sheme i konstrukcija etničke strukture u Banskoj Hrvatskoj i Slavoniji (1785.-1860.)". Migracijske $i$ etničke teme, 24/1-2:31-48.

\section{INTERNET SOURCES}

www.jusp-jasenovac.hr (accessed on 12 January 2015).

http://www.aimpress.ch/dyn/pubs/archive/data/199908/90831-002-pubs-zag.htm (accessed on 10 January 2015). 